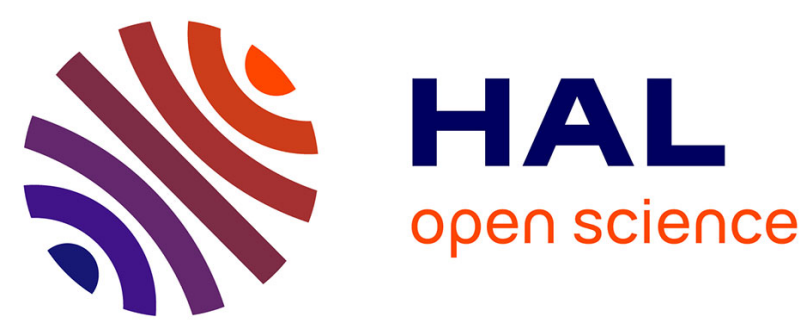

\title{
Domestic versus cross-border acquisitions: which impact on the target firms' performance?
}

Olivier Bertrand, Habib Zitouna

\section{To cite this version:}

Olivier Bertrand, Habib Zitouna. Domestic versus cross-border acquisitions: which impact on the target firms' performance?. Applied Economics, 2008, 40 (17), pp.2221-2238. 10.1080/00036840600949397. hal-00582076

\section{HAL Id: hal-00582076 \\ https://hal.science/hal-00582076}

Submitted on 1 Apr 2011

HAL is a multi-disciplinary open access archive for the deposit and dissemination of scientific research documents, whether they are published or not. The documents may come from teaching and research institutions in France or abroad, or from public or private research centers.
L'archive ouverte pluridisciplinaire HAL, est destinée au dépôt et à la diffusion de documents scientifiques de niveau recherche, publiés ou non, émanant des établissements d'enseignement et de recherche français ou étrangers, des laboratoires publics ou privés. 


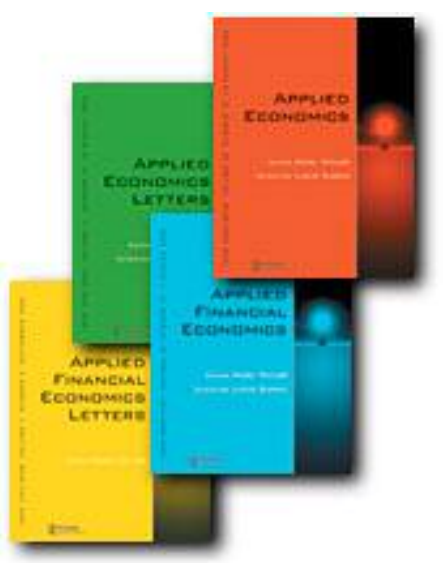

Domestic versus cross-border acquisitions: which impact on the target firms' performance?

\begin{tabular}{|c|l|}
\hline Journal: & Applied Economics \\
\hline Manuscript ID: & APE-06-0098 \\
\hline Journal Selection: & Applied Economics \\
\hline JEL Code: & $\begin{array}{l}\text { F23 - Multinational Firms } \mid \text { International Business }<\text { F2 - } \\
\text { International Factor Movements and International Business }<\text { F - } \\
\text { International Economics, F20 - General < F2 - International Factor } \\
\text { Oovements and International Business < F - International } \\
\text { Objectives, Organization, and Behavior }<\text { L - Industrial } \\
\text { Organization, L13 - Oligopoly and Other Imperfect Markets }<\text { L1 - } \\
\text { Market Structure, Firm Strategy, and Market Performance }<\text { L - } \\
\text { Industrial Organization, L20 - General }<\text { L2 - Firm Objectives, } \\
\text { Organization, and Behavior }<\text { L - Industrial Organization }\end{array}$ \\
\hline Keywords: & $\begin{array}{l}\text { Multinational Firms, Foreign Direct Investment, Mergers and } \\
\text { Acquisitions, Take-Overs, Firms Performance }\end{array}$ \\
\hline
\end{tabular}

\section{Manuscript Central ${ }^{\mathrm{TH}}$}




\title{
Domestic versus cross-border acquisitions: which impact on the
}

\author{
target firms' performance?
}

\author{
Olivier Bertrand* Habib Zitouna ${ }^{\ddagger}$
}

\begin{abstract}
This paper investigates the effects of horizontal acquisitions on the performance of target firms in the 1990's. Using French manufacturing firm-level data, we examine two main indicators of performance: the profit and the productive efficiency. We distinguish domestic from crossborder acquisitions. To evaluate the impact of take-overs, we implement appropriate differencein-difference estimation techniques associated to a matching propensity score procedure. We find that M\&A do not increase the profit of French target firms, even on the long run. However, they clearly raise the productivity of target firms. These results suggest that firms probably redistribute efficiency gains at the upstream and/or downstream production stage. There is no evidence of an increase in market power. In addition, the consequences of domestic and cross-border M\&A significantly differ. Efficiency gains are stronger for cross-border M\&A. This conclusion is however true only for extra-European Union operations. The achievement in the European economic integration certainly explains the absence of difference between European and domestic acquisitions. Finally, our results cast some doubt on the frequent discrimination attitude towards foreign takeovers and the fears of their impact on firms' performance and the host country's welfare.
\end{abstract}

Keywords : Multinational Firms, Foreign Direct Investment, Mergers and Acquisitions, TakeOvers, Firms performance.

JEL Classification : F23, L10, L20.

\footnotetext{
${ }^{*}$ Corresponding author, GREMAQ - Université de Toulouse, Manufacture des Tabacs - Bâtiment F - 21 Allée de Brienne, 31000, Toulouse ; Email: olivier.bertrand@univ-tlse1.fr

†École Supérieure des Sciences Économiques et Commerciales de Tunis (Tunisia), 4, Rue Abou Zakaria El Hafsi - Montfleury 1089 - Tunis (Tunisia). Email: Habib.Zitouna@essec.mu.tn

${ }^{\ddagger}$ We are very grateful to A-C. Disdier, B. Smarzynska Javorcik, T. Mayer, P-J. Norbäck and L. Persson. We also thank the participants at the IUI seminar (2005, Stockholm), the Journées de Microéconomie Appliquée (2005, Hammamet), the Empirical Investigations in International Economics conference (2005, Ljubjana), the European Economic Association congress (2005, Amsterdam), the International Economic Association meeting (2005, Marrakech), the CEPR conference "Competition Policy for International Development, Growth and Trade" (2005, Brussels), the GREMAQ lunch seminar (2005, Toulouse) as well as the INRA seminar (2006, Paris) for very fruitful comments and suggestions. The version presented at these conferences was entitled "M\&A and target firms' performance: are cross-border M\&A different ? Some Evidence from French firm-level data". We acknowledge the financial support from the IUI and the CEPR (research program "Competition policy in international markets") as well as the TEAM - University of Paris1 Panthéon-Sorbonne and CNRS (ACI "Dynamiques de concentration des activités économiques dans l'espace mondial").
} 


\section{Introduction}

The $20^{t h}$ century experienced a strong activity of Mergers and Acquisitions (M\&A) several times. This process of industrial restructuring has drawn attention of politicians and policy makers very early. M\&A have also become one of the most researched areas in industrial organization. Indeed, M\&A could have a major impact on firms, and thereby on industries, and their performances in particular. ${ }^{1}$ Unfortunately, empirical evidence from M\&A arrives to mixed conclusions. In the past, most studies concluded that M\&A reduce companies' productivity. ${ }^{2}$ However, more recent papers tended to highlight a rather positive impact of M\&A. ${ }^{3}$ For instance, Lichtenberg and Siegel (1987) analyzed the repercussions of ownership changes on US manufacturing plants. They observed a relative increase in the total factor productivity (TFP) of merging firms. McGuckin et al. (1995) pointed out the quicker growth in labor productivity for acquired plants in the US food industry. The performance of M\&A is also mitigated in terms of profits. ${ }^{4}$ One of the first major studies goes back to Ravenscraft and Scherer (1987). They found no support for M\&A gains. Acquired firms in the US market in the 1960's and early 1970's saw their profit decline following acquisition. These results confirm those of Meeks (1977) for the UK market. He observed lowered profits for merging firms. However, more recently, Gugler et al. (2003) came to the conclusion from a large sample of countries that mergers resulted on average in a significant increase in profits over the 1990 's decade. ${ }^{5}$

\footnotetext{
${ }^{1} \mathrm{An}$ abundant literature in finance explored the impact of M\&A on shareholders' wealth using event studies (see Meschi (1997), Andrade et al. (2001) or Pautler (2003)). It converges to say that M\&A improve the combined value of buyer and target firms. However, target shareholders take profit from M\&A while buyers just break even. In contrast, the cited literature in the remainder of the paper is based on accounting data.

${ }^{2}$ See Caves (1989) for a survey.

${ }^{3}$ The productivity indicator can be measured for each single input or for all inputs simultaneously. Although the TFP (total factor productivity) is the best way of estimating efficiency performance, labor productivity is frequently examined because of data constraint.

${ }^{4}$ Some studies analyzed the effects of M\&A on companies' market shares. Mueller (1985) or Baldwin and Gorecki (1990) found declines in market shares. Goldberg (1973), McDougall and Round (1986), Jenny and Weber (1980) or Cable et al. (1980) came to no significant variation in market shares.

${ }^{5}$ Healy et al. (1992) or for example Cosh et al. (1980) also got the result of a positive impact respectively in the US and the UK market. Empirical evidence for other countries arrives to mixed conclusions too. For instance, merging firms' profits increased in Canada (Baldwin (1995)) and Japan (Ikeda and Doi (1983)), but decreased in Holland (Peer (1980)) and Sweden (Ryden and Edberg (1980)).
} 
While empirical papers on M\&A are quite numerous, studies on cross-border M\&A only are rather scarce. The literature on cross-border M\&A is still in its infant stage. On the one hand, the industrial organization literature has explored the consequences of ownership changes on merging firms' performance, but without tackling really the issue of their nationality. It does not separate domestic from cross-border M\&A. On the other hand, the literature on multinational entreprises (MNE) has investigated the impact of foreign presence on host countries. However, it has not distinguished M\&A from Greenfield Investments. ${ }^{6}$ It traditionally considers that MNE enjoy superior knowledge-based assets and competitive ownership advantages transferable to the host country market (Hymer (1976) or e.g. Dunning (1981)). Thus, MNE's subsidiaries are expected to exhibit a higher productivity and profit compared to domestically-owned firms. This assumption seems to be supported by empirical works. ${ }^{7}$ Such questions have been only tackled very recently for cross-border M\&A. ${ }^{8}$ For instance, Arnold and Smarzynska (2005) (resp. Piscitello and Rabbiosi (2003)) found that foreign acquisitions improved the productivity of Indonesian (resp. Italian) target companies. Girma and Görg (2002) stressed the difference in the effects of M\&A across UK sectors: establishments in the electronics sector witnessed a reduction in productivity, whereas those located in the food sector saw their productivity increase. ${ }^{9}$ Some other papers compared the performance of domestic and cross-border M\&A. Conyon et al. (2002) reached the conclusion that the labor productivity of UK acquired firms increased after a foreign take-over. They decreased, but not significantly after a domestic acquisition. Gioia and Thomsen (2004) emphasized a rather negative impact of these two kinds of M\&A in the Danish market.

\footnotetext{
${ }^{6}$ A Greenfield Investment is defined as the establishment of a new production facility in contrast to a crossborder M\&A where a firm purchases shares of an existing foreign firm.

${ }^{7}$ For instance, in the UK market, Davies and Lyons (1991), Driffield (1977), Girma et al. (2000) or Griffith and Simpson (2001) confirmed the productivity superiority of foreign-owned firms. The MNE's profit is more seldom examined. For France, Houdebine and Topiol-Bensaïd (1999) pointed out that MNE's profits were higher.

${ }^{8}$ Citations are not claimed to be exhaustive, many of works on this subject being not published yet, and some of them focusing on very specific sectors, such as pharmaceutical or banking industry.

${ }^{9}$ In a related paper, Girma and Görg (2003) evaluated the impact on the survival prospects of UK target firms. Takeovers decreased their lifetime in both electronics and food sectors.
} 
This decrease in the performance of target firms was higher for cross-border M\&A. In contrast, Gugler et al. (2003) concluded to a non-important difference in profit between cross-border and domestic M\&A. ${ }^{10}$

This under-investigation of cross-border restructuring contrasts with its increasing importance in the overall M\&A activity: the 1990's opened a new wave of industrial consolidation (UNCTAD (2000)). Compared to previous phases of M\&A, this wave implied much more crossborder operations. Their number grew very quickly from 4149 in 1991 to 5373 transactions in $1998 .{ }^{11}$ Over the last decade, they represented on average one quarter of M\&A transactions, both in deal value and number. This figure could be even higher in some countries. That was the case of France where their shares (in value) increased from $41 \%$ in 1990 to $50.7 \%$ in 1999 (Coutinet and Sagot-Duvauroux (2003)). Furthermore, firms from developed countries played a preponderant role not only in outward, but also in inward cross-border M\&A (Kang and Johansson (2000)). ${ }^{12}$ For the period 1991-1998, the United States, the United Kingdom, Germany, France and Canada accounted for almost $55 \%$ of total inward M\&A deal value. The United States ranked first (27\%), followed by the United Kingdom (14\%) and France (5\%).

In addition, the surge of cross-border M\&A raises new questions in term of economic policy. It is more and more frequently asked in the public debate in Europe, and even in the United States, whether authorities should foster domestic M\&A or treat national and crossborder operations similarly. While governments are tempted to block or to discourage foreign take-overs, they usually encourage the emergence of "national champions". That is specially

\footnotetext{
${ }^{10}$ Event studies also explored the consequences of cross-border M\&A. Harris and Ravenscraft (1991) or Swenson (1993) underlined that US target firms' shareholders benefited more from a foreign M\&A than a domestic operation. Markides and Ittner (1994) focused on US outward cross-border M\&A. Cross-border operations were on average welfare-improving for the US buyers.

${ }^{11}$ The first four M\&A wave were mainly confined to the United States and Great Britain. The fifth and last M\&A wave encompassed all major industrial countries.

${ }^{12}$ We define inward cross-border M\&A as the sales of domestic firms to foreign investors. In the opposite, outward cross-border M\&A correspond to the purchases of foreign firms by domestic firms.
} 
true for France, as shown recently. In July 2005, there were some rumors about the takeover bid of the French food firm Danone by the American company PepsiCo. This rumor provoked an outcry in the French political arena, some politicians swearing to protect this French company from any foreign take-over. Few weeks later, the French government officially proposed to shield some "strategic" industries from foreign acquisitions. ${ }^{13}$ This widespread discrimination attitude is quite questionable. Unfortunately, to our knowledge, there are very few studies comparing the performance of domestic and cross-border restructuring, as explained above.

In this context, the goal of this paper is to contribute to fill this gap. We contribute to the literature in different ways. For the first time, we pursue the analysis on the French manufacturing firms' behavior in the 1990 's. ${ }^{14}$ We investigate the repercussions of horizontal acquisitions on target firms' performance from a large sample of 371 operations. ${ }^{15}$ We distinguish domestic from cross-border M\&A and compare their effects. We also divide cross-border operations according to the membership (or not) of the buyer to the European-Union, which is seldom examined, certainly because of a lack of information on the country origin of the foreign firm. Using a very detailed database at the firm-level from the EAE enquiry, we examine the changes in two complementary indicators: the TFP (rather than a measure of labour productivity) and the profit. We also account for some possible long term effects since our firm-level data covers the period 1991-2001. We implement appropriate difference-in-difference estimation techniques associated to a matching propensity score procedure. This method allows us to avoid selecting instrumental variables or limiting our analysis to a simple T-test procedure as it is done in some papers.

\footnotetext{
${ }^{13}$ This list includes ten French industries, varying from biotechnologies, secure information systems, casinos to the production of vaccines.

${ }^{14}$ In the past, two major waves of M\&A took place in France, the first one happening in the 1960's and the 1970 's, the second one in the middle of the 1980's (Derhy (1999)).

${ }^{15}$ Horizontal M\&A are defined as operations between firms within the same industry.
} 
It is found that the overall horizontal M\&A activity does not increase significantly the profit of French target firms on the short and long run. However, it exerts a positive and significant impact on their total factor productivity. These findings suggest that companies probably redistribute efficiency gains at the upstream and/or downstream production stage. There is no evidence of an increase in market power of the target firm. Besides, the repercussions of domestic and cross-border M\&A significantly differ, but only in term of productive efficiency. The impact of these two types of acquisitions on profits is still no significant. On the contrary, efficiency gains are higher for cross-border M\&A. For cross-border operations, efficiency gains could be partially transferred to the parent company through intra-firm trade and transfer prices. Multinational firms could try to minimize their fiscal burden. Nevertheless, this assumption is little plausible, because of the absence of strict upstream-downstream relationship between the buyer and the target firms. Finally, we distinguish EU from extra-EU operations: only extra-EU operations have a higher effect on efficiency gains. The achievement in the European economic integration certainly explains the similarity between European and domestic acquisitions. Our results question the discrimination attitude to cross-border acquisitions. They cast some doubt on the fears of foreign takeovers and their impact on domestic industries' performance and the host country's welfare. Positive pecuniary spill-overs are likely to be more important (or at worse identical) with cross-border operations.

The article proceeds as follows: section 2 presents the theoretical background and section 3 describes data and the measures of performance. Section 4 reports the econometric model, while section 5 discusses empirical findings. Conclusions are drawn in the last section. 


\section{Theoretical background}

As already emphasized, the infant literature on cross-border M\&A still has little to say about cross-border operations and their distinct effects as compared to domestic M\&A. However, crossborder acquisitions are both a way of restructuring industry and an entry mode on a new foreign market. Therefore, based on the traditional MNE view, it could be expected a higher performance for cross-border operations. Indeed, MNE are traditionally assumed to enjoy superior knowledge-based assets and competitive ownership advantages which allow them to compete in host country and to compensate for more fixed costs of establishments and a lack of local information, experience and business relationships (Hymer (1976) or e.g. Dunning (1981)). The transfer of technological and managerial capabilities from the parent company is likely to enhance the performance of local subsidiaries. Local subsidiaries could profit from other MNE advantages, such as a better access to foreign markets through sales affiliates or network economies. Nevertheless, there may also exist some organizational costs related to the internationalization of activities, like a loose in the management control or a lower coordination.

One the other hand, it is well-known from the industrial organization literature that a M\&A has two main implications on firms' performances. M\&A could generate unilateral anticompetitive effects (and/or coordinated effects by facilitating collusion among competing firms). The studies initiated by Salant et al. (1983) underline the limits of M\&A strategies when they are only motivated by a higher market power. However, M\&A are also driven by efficiency gains motives. Five main sorts of efficiency gains are usually listed: production rationalization (reallocation of production across firms) ; economies of scale and scope (decrease in average costs with a higher total output) ; technological progress (diffusion of know-how and increasing R\&D incentives) ; purchasing economies (lower input costs) ; lower slack (managerial and X-efficiency). 
Following the IO framework, let us discuss in what the consequences of cross-border M\&A could differ from those of domestic operations.

As concerns anti-competition effects, these are probably greater for domestic M\&A since there is more direct competition between merging firms. Geographical proximity removes some barriers to trade such as transport costs or custom duties. It reinforces competition and thus, the incentives to merge for anti-competition purposes: everything equal, two firms located in the same country compete more than two firms established in separate geographical markets. ${ }^{16} \mathrm{Nev}-$ ertheless, contrary to domestic operations, cross-border M\&A might facilitate collusive pricing behaviour across markets by increasing multi-market contacts among firms. ${ }^{17}$

Conclusions are more uncertain for efficiency improvements. Rationalization gains could be more important for cross-border operations. Merging partners are more likely to differ in their marginal production costs when they are initially located in distinct countries, because of country disparities in terms of capital and labor endowment, judicial and institutional environment, etc. In addition, they may benefit from savings in transaction costs and a better market access abroad (Bertrand and Zitouna (2006)). However, to get these efficiency gains, firms are obliged to disperse their production activities geographically across countries and then to give up some economies of scale. Furthermore, scale economies could be larger with national restructuring. Indeed, the elimination of duplicated indivisible tasks is probably more important, since firms look more alike. Besides, M\&A allow merging firms to take advantage of input purchasing economies. For example, a take-over offers new owners the opportunity to renege on implicit and explicit labor contracts (Shleifer and Summers (1988)). Lommerud et al. (2004) explored this question in an international Cournot oligopoly framework. They came to the conclusion that the wages paid by firms are lower when they merge internationally, rather than nationally: intuitively, merging

\footnotetext{
${ }^{16}$ The spatial economics literature examines the relationship between M\&A, market power and local competition (see Levy and Reitzes (1992, 1995)).

${ }^{17} \mathrm{~A}$ firm fearing retaliation in one market (i.e. a price war) is incited to moderate its pricing behavior in another market (Bernheim and Whinston (1990)).
} 
firms are able to threat unions to shift production from domestic to foreign plants, making then national and foreign unions compete on wages. ${ }^{18}$ As regards their technological implications, to some extent, stronger efficiency gains could be expected for cross-border M\&A (Bertrand and Zuniga (2006)). Merging partners are more likely to differ in terms of technological characteristics when being located in distinct technological environment, increasing assets complementary and creating a larger one-way or two-way diffusion of know-how within the firm. ${ }^{19}$ The same type of argument can be extended to managerial and organizational knowledge since M\&A represent a means of transferring the most efficient practices of a company.

However, organizational problems may prevent merging partners from performing efficiency gains. Certainly, the required organizational changes are more difficult to implement for crossborder M\&A because of a higher gap in country and/or corporate culture. Furthermore, the market for corporate control is characterized by a high asymmetry in information (Gioia and Thomsen (2004)). Foreign buyers undergo a "double lemons" problem. They have a lower monitoring capacity and are less well-informed on target characteristics due to a different accounting standard or judicial and institutional environment. Finally, buyer and target firms may not benefit equally from M\&A gains if there is a unilateral resource redeployment from target firms to buyers, or the other way round. ${ }^{20}$ Firms gain a priori more with bilateral resource redeployments. However, resource exhaustion for non-public goods, such as financial resources or managerial effort, constraints them.

\footnotetext{
${ }^{18}$ Empirical works are more ambiguous (see e.g. Conyon et al. (2002)).

${ }^{19}$ Since the economic context shapes the firms' innovation capabilities, the heterogeneity of merging firms may reflect country disparities.

${ }^{20}$ Capron and Mitchell (1998) define resource redeployment as the use by the buyer or the target firm of the other firm's resources.
} 


\section{Data description and measures of performance}

M\&A covered by our study took place from 1993 to 2000. It includes 371 M\&A divided into 202 domestic and 169 cross-border operations. M\&A data come from the Thomson One Banker Deals (formerly called Thomson Mergers) database. ${ }^{21}$ From this database, we keep all deals involving a percentage owned after the transaction superior (or equal) to $50 \%$. We also remove the firms which were acquired several times, or those which were both a target and a buyer over the given period. In addition, we exclusively focus on horizontal acquisitions, since horizontal and non-horizontal (vertical or conglomeral) operations could impact the firms' performance differently. Our sample does not comprise merger operations (conceived in their strict definition). ${ }^{22}$ The nationality and sector composition of buyer firms are respectively described by tables 1 and 2. Three main features stand out. First, US, English, Belgium and German companies were the most active foreign firms in the French market for corporate control. Second, among manufacturing sectors, industries such as metal products, mechanical, chemical or publishing were greatly affected by industrial restructuring. Finally, we observe over time an increasing tendency for both domestic and cross-border M\&A (figure 1).

All firm-based data about French companies' characteristics (1991-2001) come from the French Ministry of Industry (SESSI).$^{23}$ Based on the French census of manufacturing (EAE - Enquêtes Annuelles d'Entreprises), we estimate the French target firms' performance through two distinct measures, the EBITDA and the TFP. The EBITDA is an abbreviation for "Earn-

\footnotetext{
${ }^{21}$ These data provide information on worldwide markets from publicly announced M\&A. They comprise all transactions valued at US $\$ 1$ million or more. In order to construct this database, different sources are used, such as stock exchange commissions, trade publications, law firms, surveys of investment banks, etc.

${ }^{22}$ Cross-border acquisitions strongly predominated over mergers in the 1990's (UNCTAD (2000)). Mergers represented less than $3 \%$ of M\&A (in number). Most of them, specially cross-border acquisitions, consisted in friendly operations. Only less than $5 \%$ in value (and $0.2 \%$ in number) of completed cross-border M\&A were hostile.

${ }^{23}$ It collects each year accounting information on the inputs and outputs of individual firms. This dataset includes all French manufacturing firms of more than 20 employees. See table 8 in appendix B for more descriptive statistics.
} 
Figure 1: Evolution of domestic and cross-border M\&A

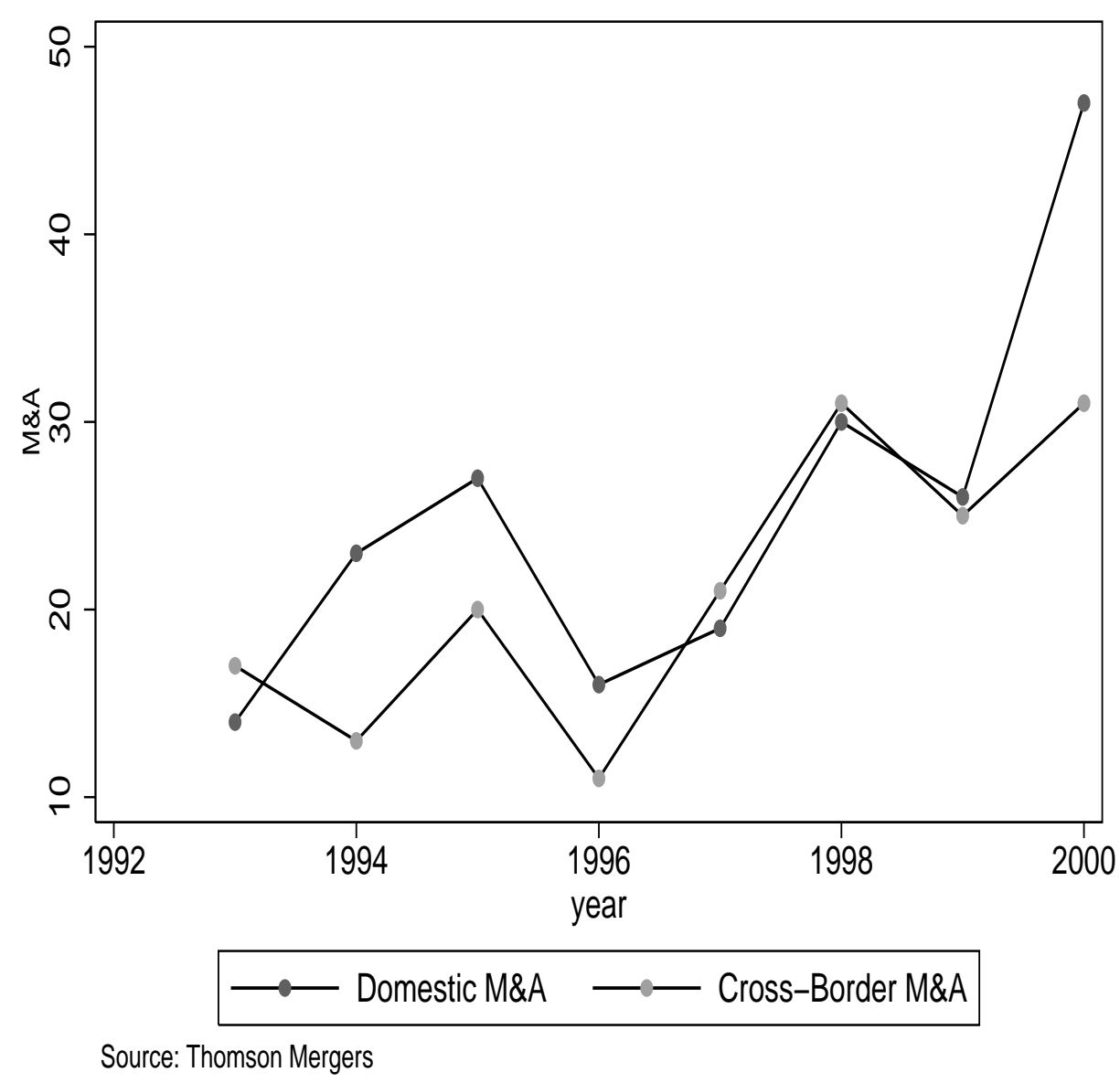


Table 1: Number of target firms by acquiror nations (1993-2000)

\begin{tabular}{|l|c|}
\hline Acquiror Nation & Target firms \\
\hline Australia & 1 \\
Austria & 3 \\
Belgium & 20 \\
Canada & 9 \\
Finland & 2 \\
France & 202 \\
Germany & 19 \\
Ireland-Rep & 1 \\
Italy & 15 \\
Japan & 4 \\
Netherlands & 11 \\
Norway & 3 \\
Spain & 4 \\
Sweden & 5 \\
Switzerland & 5 \\
United Kingdom & 21 \\
United States & 46 \\
\hline Total & 371 \\
\hline
\end{tabular}

Table 2: Number of target firms by sectors (1993-2000)

\begin{tabular}{|l|c|}
\hline Sectors & Target firms \\
\hline Clothing, leather goods & 17 \\
Publishing, printing, reproduction & 38 \\
Pharmaceutical, perfumes and cleansing/polishing & 25 \\
Household durable & 24 \\
Automobiles & 6 \\
Shipbuilding, aerospace and railway products & 9 \\
Mechanical capital goods & 46 \\
Electrical and electronic equipment & 33 \\
Mineral products & 14 \\
Textiles & 20 \\
Wood and paper & 22 \\
Chemicals, rubber, plastics & 39 \\
Metal products and metal processing & 53 \\
Electrical and electronic components & 25 \\
\hline Total & 371 \\
\hline
\end{tabular}


ings Before Interest, Taxes, Depreciation and Amortization". This indicator gives information on the company's operating profit before non-operating expenses (such as interest) and noncash charges (depreciation and amortization). It constitutes a good way of assessing profits since it eliminates the influence of financing and accounting decisions. The multilateral TFP index developed by Caves et al. (1982) and extended by Good et al. (1997) accounts for the firm productive efficiency (see appendix A for further information). ${ }^{24}$ The TFP indicator takes into consideration both scale (increasing return to scale) and technology (productivity growth) effects. In the next section, we expose the applied econometric method.

\section{The econometric methodology}

The effect of an acquisition on the outcome (here the performance) of a given firm is defined as the difference between the firm's outcome when acquired and the outcome that this firm would have reached if it had not been acquired. Put it differently, the impact of a M\&A is measured by the change in the firm's outcome which is attributable to the M\&A event only. It results in one question: what would have been the target firm's performance if it had not been taken over? The difference-in-difference (hereafter $D I D$ ) approach is well adapted to deal with this question (Meyer (1994), Heckman et al. (1997)). Considering the acquisition process as an experiment, the $D I D$ method evaluates the average effect of the treatment (here the acquisition) on treated (the acquired firms denoted $A F$ ). The idea that it develops is simple: comparing the outcome of a company before and after an acquisition is not satisfactory. Indeed, we could wrongly attribute to a $M \& A$ a variation in the outcome that is actually due to a change in the economic situation. To control this skew, and by supposing that a modification of the economic situation affects all firms in an identical way, the $D I D$ method compares the difference in the outcome before and

\footnotetext{
${ }^{24}$ See Van Biesebroeck (2003) for a discussion of the different ways to estimate productivity.
} 
after the acquisition for acquired firms to that in the outcome before and after this operation for a control group. This control group is composed of firms which has not been taken over. These firms are denoted $N A F$ in the remainder of the article.

Formally, let $Y_{i t}^{1}$ be the outcome in period $t$ for a target firm $i$ which has been exposed to a take-over. We denote $Y_{i t}^{0}$ the outcome for the same target firm if it was not subject to a take-over. The effect of the take-over for this firm $i$ is then measured by $Y_{i t}^{1}-Y_{i t}^{0}$. The average impact of acquisition is described by $E\left(Y_{i t}^{0} / A F=1\right)$. Unfortunately, missing data do not allow us to evaluate it directly: we cannot observe one same firm both as a participant and as a non-participant to a M\&A. In other words, we cannot know the outcome in the event of non-participation for a company which has actually been taken over, and conversely. To solve this difficulty, we compare the evolution of the groups $A F$ and $N A F$ assuming that they would have been identical in the absence of take-overs:

$$
E\left(Y_{i t}^{0} / A F=1, t=1\right)-E\left(Y_{i t}^{0} / A F=1, t=0\right)=E\left(Y_{i t}^{0} / A F=0, t=1\right)-E\left(Y_{i t}^{0} / A F=0, t=0\right)
$$

The terms $t=0$ and $t=1$ designate respectively the period before and after the acquisition. Thereby, the missing counterfactual value could be replaced by the state of target firms before the take-over, adjusted for the growth in aggregate outcome:

$$
E\left(Y_{i t}^{0} / A F=1, t=1\right)=E\left(Y_{i t}^{0} / A F=1, t=0\right)+m_{t}
$$

where $m_{t}=E\left(Y_{i t}^{0} / A F=0, t=1\right)-E\left(Y_{i t}^{0} / A F=0, t=0\right)$. This expression indicates the $D I D$ estimator. It assesses the impact of acquisitions on target firms. We get it by regressing data 
pooled across these two groups:

$$
Y_{i t}=\beta_{0}+\beta_{1} A F_{i}+\beta_{2} A f t e r_{t}+\beta_{3} A F_{i} * \text { After }_{t}+\varepsilon_{i t}
$$

$A F_{i}$ is a dummy variable taking the value 1 for target firms and 0 otherwise. It controls for differences in constant outcome $Y_{i t}$ between target firms and the control group. We define the dummy variable After as taking the value 1 in the post-acquisition years and 0 otherwise for both target and non-target firms. ${ }^{25}$ This dummy variable controls for time effects on outcome

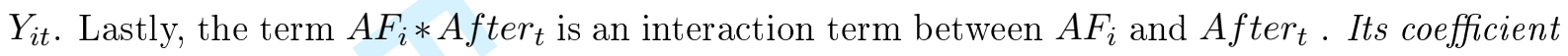
$\beta_{3}$ represents the difference-in-difference estimator of the effect of acquisition on the group AF (see the table 3). The framework described by equation (3) is extended by including a vector of firm characteristics. These explanatory variables control for differences in observable attributes between groups $A F$ and $N A F$ :

$$
Y_{i t}=\beta_{0}+\beta_{1} A F_{i}+\beta_{2} \text { After }_{t}+\beta_{3} A F_{i} * A f t e r_{t}+\Phi X_{i t}+\varepsilon_{i t}
$$

where the vector $X_{i t}$ represents the observable features of firms $i$ at time $t$.

Table 3: Difference-in-difference estimator

\begin{tabular}{|l|c|c|c|}
\cline { 2 - 4 } \multicolumn{1}{c|}{} & Before & After & Difference \\
\hline Target firms & $\beta_{0}+\beta_{1}$ & $\beta_{0}+\beta_{1}+\beta_{2}+\beta_{3}$ & $\beta_{2}+\beta_{3}$ \\
\hline Control group & $\beta_{0}$ & $\beta_{0}+\beta_{2}$ & $\beta_{2}$ \\
\hline Difference & $\beta_{1}$ & $\beta_{1}+\beta_{3}$ & $\beta_{3}$ \\
\hline
\end{tabular}

Yet, it remains to explain the choice of the comparison group. Intuitively, the DID method does not conduct to valid estimations if the comparison group already differs greatly from target firms over the pre-acquisition period. To remedy it, we combine the DID estimation to the match-

\footnotetext{
${ }^{25}$ As explained later, a newly acquired firm $i$ is associated with a non-target firm within the same year $t$.
} 
ing method (Blundell and Costa Dias (2000)). ${ }^{26}$ Propensity scores matching techniques identify a control group without markedly differences in characteristics compared to target firms. It controls for endogeneity and ex-ante observable firm characteristics (Dehejia and Wahba (2002)). Failure to account for the selection problem would bias the estimated impact of M\&A. It may lead to a correlation between being acquired and the error term in the outcome equation. It will be the case if acquisition decision is not a random process, but is due to observable firm characteristics which are also influencing the post-merger outcome. The propensity score method therefore controls for selection based on observed firm characteristics. Furthermore, matching firms directly could require comparing the groups $A F$ and $N A F$ across a too large number of observable pre-acquisition characteristics. The propensity score method reduces the dimensionality issue by capturing all information from these characteristics on a single basis (Rosenbaum and Rubin (1983)). It measures the probability of being acquired according to a vector of firm variables. The estimation of this probability value is as follows:

$$
\operatorname{Pr}\left(A F_{i t}=1\right)=F\left(X_{i t}\right)
$$

where the vector $X_{i t}$ represents the firm characteristics. Once the propensity scores calculated, observations from the group $A F$ and the $N A F$ are matched. Each target firm is associated with a control firm endowed with a similar propensity score. ${ }^{27}$ Now, this econometric methodology is applied to the performance of French target firms in the 1990's.

\footnotetext{
${ }^{26}$ The matching method is a non-parametric method. No particular specification is assumed.

${ }^{27}$ We use the 'caliper' matching method to select the control firm.
} 


\section{The econometric estimation}

\subsection{The propensity score matching}

The first stage of our estimation strategy consists in finding a well-suited control group. ${ }^{28} \mathrm{We}$ evaluate a probit of the following form:

$$
\operatorname{Pr}\left(A_{i, s, t}=1\right)=F\left(\text { TFP }_{i, s, t-1}, \text { Profit }_{i, s, t-1}, \text { Export }_{i, s, t-1}, \text { Marketshare }_{i, s, t-1}, \text { Wage }_{i, s, t-1}\right)
$$

We estimate this equation separately for domestic and cross-border acquisitions since there is no reason to expect similar variables coefficients. In addition, a newly acquired firm $i$ in a sector $s$ is matched with the closest non-target firm within the same industry $s$ and in the same year $t$ in term of its propensity score. ${ }^{29}$ By doing it, we reduce the possible bias related to unobservable temporal and sectoral determinants (such as e.g changes in regulatory environment). Indeed, the matching procedure supposes that only observable variables matters in the decision of acquisition. Moreover, to avoid some problem of endogeneity at this stage, all independent variables are lagged one year. We point out that further data are provided by the EAE database. All monetary variables are expressed in French currency (in thousands of francs) and are deflated using 1995 prices as a benchmark. It should be noticed that the variables are not expressed in logarithm in this paper because some of them take zero or negative values.

We select different determinants of acquisition. ${ }^{30}$ We include both the TFP and the profit: the propensity of a firm to be taken over basically depends on its performance. In addition, we account for the firm's relative size, that says its market share. The size is not directly evaluated

\footnotetext{
${ }^{28}$ The matching is performed in Stata Version 8 implementing the software provided by Sianesi (2001).

${ }^{29}$ We use the French industry classification $N A F 16$.

${ }^{30}$ We checked that there is neither a too high statistic correlation, nor multi-collinearity among selected variables.
} 
by the turnover because of a high correlation with the profit variable. Finally, we control for the export rate of the target firm as well as the wage by employee. Our main findings provided in the second stage of our estimation strategy (OLS) are actually quite robust to a change in the set of explanatory variables or their measure (e.g. lagged or not, expressed as a growth rate or not) as well as the employed specification (as matching within the same industry or not).

Based on the pooled cross-section data, the tables 9 and 10 in appendix $\mathrm{C}$ display the efficiency of the matching procedure. The balancing property is verified. ${ }^{31}$ The reduction in bias is drastic for both domestic and foreign take-overs when the bias is initially high. ${ }^{32}$ Once reduced, the bias does not exceed the threshold of $8 \%$ (resp. 16\%) for domestic (foreign) acquisitions. In both cases, it is very low for our two main variables of interest. It is less than $5 \%$ for the TFP and profit variables. This method thus provides a valid group of firms to which we will compare changes in target firms' performance.

Finally, it is pointed out in table 11 in appendix $\mathrm{C}$ that the probability of being acquired is negatively and significantly related to the TFP. On the contrary, the profit variable is still negative, but not significant. ${ }^{33}$ A poorly-performing firm seems more likely to be acquired. An acquisition may act as a managerial disciplining device to remove bad managers. Moreover, by taking-over a low-performing firm, an investor may expect to implement his more efficient organizational and technological practices, thereby generating efficiency gains. ${ }^{34}$ The next step is to estimate the equation 4 .

\footnotetext{
${ }^{31}$ For each independent variable, the difference between target and control firms is checked, employing T-test on the differences within bands of the propensity score.

${ }^{32}$ The bias could be defined as the difference of the sample mean in the treated and non-treated sub-samples divided by the square root of the average of the sample variances in the treated and non-treated groups.

${ }^{33}$ This non-significance may come from a size effect. Large firms with lower profits could be more likely to be acquired. By buying out a large firm, a company increases more quickly its business activity, taking profit from economies of scale and scope: it is precisely an advantage of external growth strategies over those of internal growth.

${ }^{34}$ However, such a view has been mitigated by Ravenscraft and Scherer (1989) or Jensen (1986). M\&A are an ambivalent phenomenon. They sometimes reflect managers' power. In addition, investors could be incited to take over high-performing firms in order to benefit from their technological and managerial knowledge.
} 


\subsection{The difference-in-difference estimation}

We estimate the effects of acquisitions by performing the Ordinary Least Squares (OLS) method with robust standard errors. Table 4 shows their repercussions in terms of productivity. Table 5 indicates the impact of M\&A on profits. By including in the regressions both fixed year and sector dummies, we account for unobserved constant heterogeneity across industries (like e.g. regulatory environment) as well as external shocks which are likely to play a role in the performance of firms. For presentation and clarity purposes, empirical results with no fixed effects or firm fixed effects only are available upon request. Note that taking them into account does not affect our main conclusions. In each table, we first estimate the whole sample (columns 1 to 5) and then separate data into domestic and cross-border acquisitions (columns 6 to 10). In addition, we evaluate the impact of M\&A with and without controlling variables to verify the robustness of our conclusions. We control for the influence of the company' size (variable Size). It corresponds to the firm's turnover, which reflects its business activity. We also evaluate the role of the firm's market share (variable Marketshare) and the industry concentration (variable $H H)$. The industry concentration rate is calculated using the traditional Herfindahl-Hirschman index. This index is equal to the sum of the squares of firms' market shares in a given sector (Martin, 1993). The firm's market share, the industrial concentration and all sector dummies are calculated at the very disaggregated level $N A F 114$ (French industry classification). Because of a high correlation (around 0.58), interpreting simultaneously the variable $H H$ and Marketshare is difficult. However, there seems to be no multi-collinearity issue when implementing a VIF (Variance Inflating Factors) test. In addition to different fixed effects specifications, these variables permit to control for variations in observable characteristics of the market structure and firms.

In a first step, we examine the productivity of acquired firms (table 4). The variable AF*After 
displays a positive and significant sign in all TFP regressions. It suggests that M\&A increase the productive efficiency of target firms. As seen in the previous section, the likelihood of being taken over depends negatively on the variable TFP (table 11 in appendix C). Hence, it confirms that buyers tend to take possession of inefficient companies, certainly in order to improve their efficiency. This conclusion converges with recent studies highlighting a positive impact of M\&A in term of productivity (e.g. McGuckin et al. (1995)). Then, we break up total acquisitions into national and cross-border operations. We replace the variable $A F$ with two different dummy variables: $A F$ dom and $A F$ trs. Two interactive dummies are then included: AF dom*After and AF trs ${ }^{*}$ After. The coefficients of these interactive dummy variables indicate the impact of domestic and cross-border acquisitions respectively. As shown by table 4, M\&A have a positive impact for both domestic and foreign acquisitions. The positive sign from cross-border acquisitions supports works from Arnold and Smarzynska (2005) or for instance Piscitello and Rabbiosi (2003). ${ }^{35}$ The foreign acquisitions of target firms are followed by an improvement in productivity. Interestingly, the coefficient size is quite larger for cross-border acquisitions as compared to domestic operations. This difference is significative when applying a Wald test (at less than 5\% level). Efficiency gains appear to be higher for cross-border M\&A, confirming some theoretical intuitions developed in section $2 .{ }^{36}$ Complementarity in knowledge assets could be more important with cross-border operations, facilitating the redeployment of technological and managerial capabilities. We also show in table 6 the estimations when we split up crossborder M\&A into two distinct samples: the buyers belong or not to the European Community. The variables AF trs $E^{*} A f t e r$ and AF trs $N E^{*} A f t e r$ designate respectively the effects of intra and extra-EU cross-border M\&A. National, intra-EU and extra-EU M\&A affect positively the target firms' TFP. Furthermore, the difference between domestic and cross-border M\&A is sig-

\footnotetext{
${ }^{35}$ Conyon et al. (2002) and Piscitello and Rabbiosi (2003) only take into account changes in labor productivity.

${ }^{36}$ Our results partly differ for instance from Conyon et al. (2002). They did not found any significant increase in productivity for domestic M\&A.
} 
nificative when applying a Wald test, but only for non-European M\&A (at less than $5 \%$ level). ${ }^{37}$ Only non-European M\&A are more efficiency-improving than domestic M\&A. It certainly comes from the achievement in the European economic integration. This process progressively lowered transaction costs and facilitated market access to all European countries. It certainly also made institutional and economic environment more homogenous across European countries. Therefore, although the motive of the European integration is to allow firms to reap scale effects and improve competitiveness, it does mean that an intra-European industrial consolidation is more efficient. As explained in the section 2, French/extra-European partners are more likely to differ in their marginal production costs compared to merging French/European firms since country disparities in terms of capital and labor endowment, judicial and institutional environment, are certainly more predominant between the French and the extra-European market. It should be pointed out that U.S firms account for the greatest majority of extra-European buyers. Therefore, this result mainly turns out to be a U.S. versus European distinction in productive performance.

More generally, this finding highlights that the country origin of the buyer firm matters. We test the robustness of these outcomes by removing sector and year dummies, or including firm dummies. It gives support for our prior conclusions. ${ }^{38}$

\footnotetext{
${ }^{37}$ The difference between domestic and European M\&A is not significant even at a threshold of $10 \%$.

${ }^{38}$ The inclusion of firm dummies makes the interactive variable not significant for domestic operations. However, the consequences of foreign operations still remain positive and significant, confirming a higher efficiency for crossborder M\&A, especially non-European M\&A.
} 
Table 4: Effects of M\&A on TFP

\begin{tabular}{|c|c|c|c|c|c|c|c|c|c|c|}
\hline & (1) & (2) & (3) & (4) & (5) & (6) & (7) & $(8)$ & (9) & (10) \\
\hline $\begin{array}{l}\text { After } \\
\text { AF }\end{array}$ & $\begin{array}{c}-3.398 \mathrm{e}-02 \\
(4.628 \mathrm{e}-02) \\
-.284^{a}\end{array}$ & $\begin{array}{l}-2.673 \mathrm{e}-02 \\
(4.620 \mathrm{e}-02) \\
\left.-.2755^{a}\right)\end{array}$ & $\begin{array}{c}-6.599 \mathrm{e}-03 \\
(4.595 \mathrm{e}-02) \\
-.271^{a}\end{array}$ & $\begin{array}{c}-2.711 \mathrm{e}-02 \\
(4.623 \mathrm{e}-02) \\
-.276^{a}\end{array}$ & $\begin{array}{c}-6.507 \mathrm{e}-03 \\
(4.598 \mathrm{e}-02) \\
-.270^{a}\end{array}$ & $\begin{array}{l}-3.533 \mathrm{e}-02 \\
(4.635 \mathrm{e}-02)\end{array}$ & $\begin{array}{l}-2.821 \mathrm{e}-02 \\
(4.626 \mathrm{e}-02)\end{array}$ & $\begin{array}{l}-8.076 \mathrm{e}-03 \\
(4.601 \mathrm{e}-02)\end{array}$ & $\begin{array}{l}-2.858 \mathrm{e}-02 \\
(4.629 \mathrm{e}-02)\end{array}$ & $\begin{array}{r}-7.971 \mathrm{e}-03 \\
(4.603 \mathrm{e}-02)\end{array}$ \\
\hline $\mathrm{AF}$ & $(5.193 \mathrm{e}-02)$ & $(5.178 \mathrm{e}-02)$ & $(5.085 \mathrm{e}-02)$ & $(5.180 \mathrm{e}-02)$ & $(5.086 \mathrm{e}-02)$ & 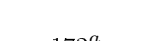 & 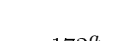 & & & \\
\hline $\begin{array}{l}\text { AF Dom } \\
\text { AF Trs }\end{array}$ & & & & & & $\begin{array}{c}-.172^{a} \\
(6.203 \mathrm{e}-02) \\
-.426^{a} \\
(6.679 \mathrm{e}-02)\end{array}$ & $\begin{array}{c}-.172^{a} \\
(6.171 \mathrm{e}-02) \\
-.407^{a} \\
(6.689 \mathrm{e}-02)\end{array}$ & $\begin{array}{c}-.158^{a} \\
(6.064 \mathrm{e}-02) \\
-.413^{a} \\
(6.566 \mathrm{e}-02)\end{array}$ & $\begin{array}{c}-.1733^{a} \\
(6.172 \mathrm{e}-02) \\
-.407^{a} \\
(6.690 \mathrm{e}-02)\end{array}$ & $\begin{array}{c}-.158^{a} \\
(6.065 \mathrm{e}-02) \\
-.413^{a} \\
(6.567 \mathrm{e}-02)\end{array}$ \\
\hline AF*After & $\begin{array}{c}.277^{a} \\
(5.923 \mathrm{e}-02)\end{array}$ & $\begin{array}{c}.280^{a} \\
(5.907 \mathrm{e}-02)\end{array}$ & $\begin{array}{c}.259^{a} \\
(5.840 \mathrm{e}-02)\end{array}$ & $\begin{array}{c}.281^{a} \\
(5.907 \mathrm{e}-02)\end{array}$ & $\begin{array}{c}.259^{a} \\
(5.841 \mathrm{e}-02)\end{array}$ & & & & & \\
\hline $\begin{array}{l}\text { AF Dom*After } \\
\text { AF Trs*After }\end{array}$ & & & & & & $\begin{array}{c}.187^{a} \\
(7.050 \mathrm{e}-02) \\
.383^{a} \\
(7.516 \mathrm{e}-02)\end{array}$ & $\begin{array}{c}.182^{a} \\
(7.019 \mathrm{e}-02) \\
.396^{a} \\
(7.502 \mathrm{e}-02)\end{array}$ & $\begin{array}{c}.163^{b} \\
(6.952 \mathrm{e}-02) \\
.371^{a} \\
(7.402 \mathrm{e}-02)\end{array}$ & $\begin{array}{c}.183^{a} \\
(7.019 \mathrm{e}-02) \\
.396^{a} \\
(7.500 \mathrm{e}-02)\end{array}$ & $\begin{array}{c}.163^{b} \\
(6.954 \mathrm{e}-02) \\
.371^{a} \\
(7.403 \mathrm{e}-02)\end{array}$ \\
\hline $\begin{array}{l}\text { Size } \\
\text { Marketshare }\end{array}$ & & $\begin{array}{r}-6.513 \mathrm{e}-08^{a} \\
(1.655 \mathrm{e}-08)\end{array}$ & $\begin{array}{c}3.156 \mathrm{e}-08^{b} \\
(1.240 \mathrm{e}-08) \\
\left.-6.064^{a}\right) \\
(.537)\end{array}$ & $\begin{array}{l}-6.482 \mathrm{e}-08^{a} \\
(1.643 \mathrm{e}-08)\end{array}$ & $\begin{array}{c}3.166 \mathrm{e}-08^{b} \\
(1.237 \mathrm{e}-08) \\
\left.-6.073^{a}\right) \\
(.536)\end{array}$ & & $\begin{array}{c}-6.295 \mathrm{e}-08^{a} \\
(1.628 \mathrm{e}-08)\end{array}$ & $\begin{array}{c}3.505 \mathrm{e}-08^{a} \\
(1.214 \mathrm{e}-08) \\
-6.115^{a} \\
(.536)\end{array}$ & $\begin{array}{l}-6.264 \mathrm{e}-08^{a} \\
(1.616 \mathrm{e}-08)\end{array}$ & $\begin{array}{c}3.515 \mathrm{e}-08^{a} \\
(1.212 \mathrm{e}-08) \\
-6.126^{a} \\
(.534)\end{array}$ \\
\hline $\begin{array}{l}\mathrm{HH} \\
\text { Constant }\end{array}$ & $\begin{array}{c}-.819^{a} \\
(8.492 \mathrm{e}-02)\end{array}$ & $\begin{array}{c}-.826^{a} \\
(8.474 \mathrm{e}-02)\end{array}$ & $\begin{array}{c}-1.602^{a} \\
(9.418 \mathrm{e}-02)\end{array}$ & $\begin{array}{c}-8.374 \mathrm{e}-05 \\
(7.729 \mathrm{e}-05) \\
\left.-1.545^{a}\right) \\
(.110)\end{array}$ & $\begin{array}{c}1.374 \mathrm{e}-05 \\
(7.749 \mathrm{e}-05) \\
\left.-1.612^{a}\right) \\
(.108)\end{array}$ & $\begin{array}{c}-1.451^{a} \\
(.105)\end{array}$ & $\begin{array}{c}-1.471^{a} \\
(.104)\end{array}$ & $\begin{array}{c}-1.457^{a} \\
(.103)\end{array}$ & $\begin{array}{c}-8.242 \mathrm{e}-05 \\
(7.755 \mathrm{e}-05) \\
-1.413^{a} \\
(.118)\end{array}$ & $\begin{array}{c}1.583 \mathrm{e}-05 \\
(7.783 \mathrm{e}-05) \\
-1.468^{a} \\
(.117)\end{array}$ \\
\hline Observations & $\begin{array}{l}6380 \\
0.44\end{array}$ & $\begin{array}{r}6380 \\
0.44\end{array}$ & $\begin{array}{l}6380 \\
0.46\end{array}$ & $\begin{array}{l}6380 \\
0.44\end{array}$ & $\begin{array}{l}6380 \\
0.46\end{array}$ & $\begin{array}{l}6380 \\
0.44\end{array}$ & 6380 & $\begin{array}{l}6380 \\
0.46\end{array}$ & 6380 & 6380 \\
\hline $\begin{array}{l}\text { R-squared } \\
\text { Sector and ye }\end{array}$ & $\frac{0.44}{\text { effects }}$ & 0.44 & 0.46 & 0.44 & 0.46 & 0.44 & & 0.46 & 0.45 & 0.46 \\
\hline
\end{tabular}


In a second step, we explore the profits of target firms. As described by the table 5, acquisitions have contrasted consequences on their performance. The variable $A F^{*} A f t e r$ is indeed positive, but not significant. Contrary to the recent work from Gugler et al. (2003), the profit of target firms does not significantly increase (or decrease as e.g. in Ravenscraft and Scherer (1987)) following an acquisition. In addition, we investigate the time horizon in the impact of acquisitions. The effects on profit could take more time. Results are then restricted for more than 2, 3, 4 or 5 years (only) after the acquisition. Actually, as indicated in table 7, acquisitions do not seem to increase profits, even on the long run. ${ }^{39}$ French target firms do not seem to keep their efficiency gains. Under competitive pressure, efficiency gains could be redistributed at the upstream and/or downstream production stage, through an increase in input prices and/or a decrease in final good prices. ${ }^{40}$ Thus, there is no evidence of any significant increase in the market power of target firms, since profits do not vary. Then, columns 6 to 10 in table 5 decompose acquisitions into domestic and foreign operations. Domestic M\&A do not have a significant impact on target firms' profits. In spite of higher efficiency gains, cross-border operations do not drive to a variation in profits either. There could be two main explanations. First, the reduction in competition is weaker for cross-border M\&A. It does not allow firms to profit from their higher efficiency gains. Second, there are some wealth transfers from the newly affiliate to the parent company. Transfer pricing mechanisms could be used by MNE to minimize their global tax burden. ${ }^{41}$ They could manipulate transfer prices to shift profits from one high-tax to a low-tax country through intra-firm trade. ${ }^{42}$ Because of the high level of tax rate on profits in France, this scenario could sound realistic. However, our sample only includes horizontal acquisitions.

\footnotetext{
${ }^{39}$ The interactive variable could be significant in 3 , but not in 2,4 or 5 . This change is then not really conclusive, all the more as the significance is not robust to a modification in estimations. More generally, we have to interpret it with caution since our sample is reduced with a narrower timing window.

${ }^{40}$ Theoretically, three main parameters determine the extent to which efficiency gains reduce consumers' prices: the intensity of competition after merging, the characteristics of the demand function and the production cost.

${ }^{41}$ See Caves (1996) for an overview on this question.

${ }^{42}$ They could modify the prices assigned to internal transactions, by under-pricing exports and over-pricing imports.
} 
It therefore roughly exclude upstream - downstream relationship. Transfer pricing techniques should then be confined to intangible goods only, such as royalty payment for patents, trademarks etc. In this context, profit evasion should be limited. Finally, we display estimations in table 6 when separating cross-border M\&A into non-European and European acquisitions. We again test the robustness of our outcomes by removing sector and year dummies, or including firm dummies. Findings are similar. 
Table 5: Effects of M\&A on profits

\begin{tabular}{|c|c|c|c|c|c|c|c|c|c|c|}
\hline & (1) & & (3) & (4) & $(5)$ & (6) & (7) & (8) & (9) & (10) \\
\hline After & $1.402 \mathrm{e}+04^{a}$ & $5.839 \mathrm{e}+03^{c}$ & $6.180 \mathrm{e}+03^{c}$ & $5.801 \mathrm{e}+03^{c}$ & $6.136 \mathrm{e}+03^{c}$ & $1.405 \mathrm{e}+04^{a}$ & $5.787 \mathrm{e}+03^{c}$ & $6.135 \mathrm{e}+03^{c}$ & $5.749 \mathrm{e}+03^{c}$ & $6.092 \mathrm{e}+03^{c}$ \\
\hline$A 1$ & (5.425e+03) & $(3.196 \mathrm{e}+03)$ & $(3.203 \mathrm{e}+03)$ & $(3.204 \mathrm{e}+03)$ & $(3.211 \mathrm{e}+03)$ & $(5.413 \mathrm{e}+03)$ & $(3.192 \mathrm{e}+03)$ & $(3.199 \mathrm{e}+03)$ & $(3.200 \mathrm{e}+03)$ & $(3.207 \mathrm{e}+03)$ \\
\hline $\mathrm{AF}^{\prime}$ & $\begin{array}{c}2.928 \mathrm{e}+03 \\
(2.806 \mathrm{e}+03)\end{array}$ & $\begin{array}{l}-6.898 \mathrm{e} e+03^{3} \\
(2.039 \mathrm{e}+03)\end{array}$ & $\begin{array}{l}-6.786 \mathrm{e}+03^{3} \\
(2.000 \mathrm{e}+03)\end{array}$ & $\frac{-6.948 \mathrm{e}+030^{4}}{(2.054 \mathrm{e}+03)}$ & & & & & & \\
\hline AF Dom & & & & & & $\begin{array}{c}-2.009 e+03 \\
(2.593 e+03)\end{array}$ & $\begin{array}{l}-2.013 \mathrm{e}+03 \\
\end{array}$ & $\begin{array}{c}-1.767 \mathrm{e}+03 \\
(1.521 \mathrm{e}+03)\end{array}$ & $\begin{array}{c}-2.071 \mathrm{e}+03 \\
(1.487 \mathrm{e}+03)\end{array}$ & $\begin{array}{r}-1.822 \mathrm{e}+03 \\
(1.520 \mathrm{e}+03)\end{array}$ \\
\hline AF $\operatorname{Trs}$ & & & & & & $1.002 \mathrm{e}+04^{b}$ & $-1.316 \mathrm{e}+04^{a}$ & $-1.323 \mathrm{e}+04^{a}$ & $-1.320 \mathrm{e}+04^{a}$ & $-1.326 \mathrm{e}+04^{a}$ \\
\hline AF*After & $6.453 e+03$ & & $3.434 \mathrm{e}+03$ & $3.844 \mathrm{e}+03$ & $3.482 \mathrm{e}+03$ & $(4.745 \mathrm{e}+03)$ & $(3.666 \mathrm{e}+03)$ & $(3.702 \mathrm{e}+03)$ & $(3.680 \mathrm{e}+03)$ & $(3.712 \mathrm{e}+03)$ \\
\hline thect & $(8.623 e+03)$ & $(5.512 \mathrm{e}+03)$ & $(5.406 \mathrm{e}+03)$ & $(5.525 \mathrm{e}+03)$ & $(5.421 \mathrm{e}+03)$ & & & & & \\
\hline AF Dom*After & & & & & & $\begin{array}{c}-8.195 \mathrm{e}+03 \\
(5.682 \mathrm{e}+03)\end{array}$ & $\begin{array}{c}-1.145 \mathrm{e}+03 \\
(4.209 \mathrm{e}+03)\end{array}$ & $\begin{array}{c}-1.470 \mathrm{e}+03 \\
(4.181 \mathrm{e}+03)\end{array}$ & $\begin{array}{c}-1.073 \mathrm{e}+03 \\
(4.214 \mathrm{e}+03)\end{array}$ & $\begin{array}{c}-1.400 \mathrm{e}+03 \\
(4.184 \mathrm{e}+03)\end{array}$ \\
\hline AF Trs*After & & & & & & $2.380 \mathrm{e}+04$ & $9.593 \mathrm{e}+03$ & $9.152 \mathrm{e}+03$ & $9.597 \mathrm{e}+03$ & $9.171 \mathrm{e}+03$ \\
\hline Size & & $7.443 \mathrm{e}-02^{a}$ & $7.588 \mathrm{e}-02^{a}$ & $7.446 \mathrm{e}-02^{a}$ & $7.585 \mathrm{e}-02^{a}$ & $(1.700 e+04)$ & $\begin{array}{l}(9.708 \mathrm{e}+03) \\
\quad 7.453 \mathrm{e}-02^{a}\end{array}$ & $\begin{array}{l}(9.575 \mathrm{e}+03) \\
\quad 7602 \mathrm{e}-02^{a}\end{array}$ & $\begin{array}{l}(9.709 \mathrm{e}+03) \\
\left.\quad 7.456 \mathrm{e}-02^{a}\right)\end{array}$ & $\begin{array}{l}(9.582 \mathrm{e}+03) \\
7.599 \mathrm{e}-02^{a}\end{array}$ \\
\hline Mark & & $(9.373 \mathrm{e}-03)$ & $\begin{array}{c}(1.084 \mathrm{e}-02) \\
-8.947 \mathrm{e}+04\end{array}$ & $(9.373 \mathrm{e}-03)$ & $\begin{array}{c}(1.084 \mathrm{e}-02) \\
-8.614 \mathrm{e}+04\end{array}$ & & $(9.348 \mathrm{e}-03)$ & $\begin{array}{l}(1.083 \mathrm{e}-02) \\
-9.161 \mathrm{e}+04\end{array}$ & $(9.347 \mathrm{e}-03)$ & $\begin{array}{r}(1.083 \mathrm{e}-02) \\
-8.833 \mathrm{e}+04\end{array}$ \\
\hline Marketshare & & & $\begin{array}{l}-8.947 \mathrm{e}+04 \\
(1.106 \mathrm{e}+05)\end{array}$ & & $\begin{array}{l}-8.614 \mathrm{e}+04 \\
(1.103 \mathrm{e}+05)\end{array}$ & & & $(1.109 \mathrm{e}+05)$ & & $\begin{array}{l}-8.833 \mathrm{3e}+04 \\
(1.106 \mathrm{e}+05)\end{array}$ \\
\hline $\mathrm{HH}$ & & & & $\begin{array}{l}-6.489 \\
(5.453)\end{array}$ & $\begin{array}{l}-5.267 \\
(5.085)\end{array}$ & & & & $\begin{array}{l}-6.434 \\
(5.431)\end{array}$ & $\begin{array}{l}-5.182 \\
(5.065)\end{array}$ \\
\hline Constant & $\begin{array}{c}1.033 \mathrm{e}+04 \\
(.)\end{array}$ & $\begin{array}{l}4.395 \mathrm{e}+03^{a} \\
(7.470 \mathrm{e}+02)\end{array}$ & $\begin{array}{c}3.946 \mathrm{e}+04 \\
(3.816 \mathrm{e}+04)\end{array}$ & $\begin{array}{c}4.696 \mathrm{e}+04 \\
(4.004 \mathrm{e}+04)\end{array}$ & $\begin{array}{c}4.635 \mathrm{e}+04 \\
(3.976 \mathrm{e}+04)\end{array}$ & $\begin{array}{r}-1.272 \mathrm{e}+03 \\
(7.287 \mathrm{e}+03)\end{array}$ & $\begin{array}{l}2.213 \mathrm{e}+04^{a} \\
(6.084 \mathrm{e}+03)\end{array}$ & $\begin{array}{c}3.514 \mathrm{e}+04 \\
(3.738 \mathrm{e}+04)\end{array}$ & $\begin{array}{c}4.667 \mathrm{e}+04 \\
(3.989 \mathrm{e}+04)\end{array}$ & $\begin{array}{c}4.605 \mathrm{e}+04 \\
(3.961 \mathrm{e}+04)\end{array}$ \\
\hline Observations & 016 & 6897 & 6897 & 6897 & 6897 & 6897 & 6897 & 6897 & 6897 & 6897 \\
\hline R-squa & 0.16 & 0.63 & 0.63 & & 0.63 & & 0.63 & 0.63 & 0.63 & \\
\hline
\end{tabular}


Table 6: Effects of intra-EU and extra-EU cross-border M\&A

\begin{tabular}{|l|c|c|}
\hline & Profit & TFP \\
\hline After & $6.148 \mathrm{e}+03^{c}$ & $-7.121 \mathrm{e}-03$ \\
& $(3.208 \mathrm{e}+03)$ & $(4.602 \mathrm{e}-02)$ \\
AF Dom & $-1.920 \mathrm{e}+03$ & $-.161^{a}$ \\
& $(1.536 \mathrm{e}+03)$ & $(6.065 \mathrm{e}-02)$ \\
AF Trs E & $-8.421 \mathrm{e}+03^{a}$ & $-.333^{a}$ \\
& $(2.519 \mathrm{e}+03)$ & $(7.747 \mathrm{e}-02)$ \\
AF Trs NE & $-2.117 \mathrm{e}+04^{a}$ & $-.555^{a}$ \\
& $(8.058 \mathrm{e}+03)$ & $(9.667 \mathrm{e}-02)$ \\
AF Dom*After & $-1.404 \mathrm{e}+03$ & $.164^{b}$ \\
& $(4.185 \mathrm{e}+03)$ & $(6.955 \mathrm{e}-02)$ \\
AF Trs E*After & $-6.384 \mathrm{e}+03$ & $.252^{a}$ \\
& $(5.537 \mathrm{e}+03)$ & $(8.849 \mathrm{e}-02)$ \\
AF Trs NE*After & $3.071 \mathrm{e}+04$ & $.553^{a}$ \\
Size & $(2.044 \mathrm{e}+04)$ & $(.107)$ \\
& $7.576 \mathrm{e}-02^{a}$ & $3.563 \mathrm{e}-08^{a}$ \\
Marketshare & $(1.076 \mathrm{e}-02)$ & $(1.204 \mathrm{e}-08)$ \\
& $-8.413 \mathrm{e}+04$ & $-6.101^{a}$ \\
HH & $(1.103 \mathrm{e}+05)$ & $(.536)$ \\
& -5.811 & $1.081 \mathrm{e}-05$ \\
Constant & $(5.174)$ & $(7.788 \mathrm{e}-05)$ \\
& $5.029 \mathrm{e}+04$ & $-1.544^{a}$ \\
\hline Observations & $(4.053 \mathrm{e}+04)$ & $(.123)$ \\
R-squared & 6897 & 6380 \\
\hline Sector and year fixed effects are included. & 0.46 \\
Robust standard errors in parentheses & \\
$*$ & 0.63 significant at $10 \%{ }^{b}$ significant at $5 \%{ }^{a}{ }^{a}$ significant at $1 \%$ \\
\hline
\end{tabular}


Table 7: Long term effects of M\&A on profits

\begin{tabular}{|c|c|c|c|c|c|c|c|c|}
\hline & $>2$ & $>3$ & $>4$ & $>5$ & $>2$ & $>3$ & $>4$ & $>5$ \\
\hline After & $5.985 \mathrm{e}+03$ & $1.361 \mathrm{e}+04^{c}$ & $1.688 \mathrm{e}+04$ & $1.053 \mathrm{e}+04$ & $5.957 \mathrm{e}+03$ & $1.346 \mathrm{e}+04^{\mathrm{c}}$ & $1.660 \mathrm{e}+04$ & $9.977 \mathrm{e}+03$ \\
\hline & $(5.722 \mathrm{e}+03)$ & $(7.583 e+03)$ & $(1.083 e+04)$ & $(0.71)$ & & & & \\
\hline $\mathrm{AF}$ & $\begin{array}{c}-4.239 \mathrm{e}+03 \\
(3.620 \mathrm{e}+03\end{array}$ & $\begin{array}{c}2.173 e+03 \\
(5.293 e+03)\end{array}$ & $\begin{array}{c}6.017 \mathrm{e}+03 \\
(7.456 \mathrm{e}+03\end{array}$ & $\begin{array}{c}9.463 e+03 \\
(0.91)\end{array}$ & & & & \\
\hline AF Dom & & & & & $-2.425 \mathrm{e}+03$ & $3.278 \mathrm{e}+03$ & $5.819 \mathrm{e}+03^{c}$ & $6.118 \mathrm{e}+03$ \\
\hline AF Trs & & & & & $\begin{array}{l}(2.661 \mathrm{e}+03) \\
-5.821 \mathrm{e}+03\end{array}$ & $\begin{array}{c}(2.846 \mathrm{e}+03) \\
1.262 \mathrm{e}+03\end{array}$ & $\begin{array}{c}(3.290 \mathrm{e}+03) \\
5.932 \mathrm{e}+03\end{array}$ & $\begin{array}{c}(3.840 \mathrm{e}+03) \\
1.243 \mathrm{e}+04\end{array}$ \\
\hline$A F * A f t e r$ & & & & & $(6.220 \mathrm{e}+03)$ & $(9.865 \mathrm{e}+03)$ & $(1.548 \mathrm{e}+04)$ & $(2.066 \mathrm{e}+04)$ \\
\hline AF Atter & $\begin{array}{c}5.896 \mathrm{e}+03 \\
(5.914 \mathrm{e}+03)\end{array}$ & $\begin{array}{l}1.0998 \mathrm{e}+04 \\
(6.388 \mathrm{e}+03)\end{array}$ & $\begin{array}{c}1.013 \mathrm{e}+04 \\
(8.821 \mathrm{e}+03)\end{array}$ & $\begin{array}{l}1.291 \mathrm{e}+04 \\
(1.08)\end{array}$ & & & & \\
\hline AF Dom*After & & & & & $\begin{array}{c}-2.234 \mathrm{e}+03 \\
(4.324 \mathrm{e}+03)\end{array}$ & $\begin{array}{c}2.386 \mathrm{e}+03 \\
(3.028 \mathrm{e}+03)\end{array}$ & $\begin{array}{l}6.584 \mathrm{e}+02 \\
(3.483 \mathrm{e}+03\end{array}$ & $\begin{array}{c}3.499 \mathrm{e}+03 \\
(4.032 \mathrm{e}+03\end{array}$ \\
\hline AF Trs*After & & & & & $1.522 \mathrm{e}+04$ & $2.141 \mathrm{e}+04^{c}$ & $2.281 \mathrm{e}+04$ & $2.487 \mathrm{e}+04$ \\
\hline & & $78200^{a}$ & & $82100_{0}^{a}$ & $(9.728 \mathrm{e}+03)$ & $(1.252 \mathrm{e}+04)$ & $(1.829 \mathrm{e}+04)$ & $(2.386 \mathrm{e}+04)$ \\
\hline Dize & $\begin{array}{l}8.084 \mathrm{e}-02 \\
(1.277 \mathrm{e}-02)\end{array}$ & $\begin{array}{l}(.832 \mathrm{e}-02 \\
(1.307 \mathrm{e}-02)\end{array}$ & $\begin{array}{l}(.823 \mathrm{e}-02 \\
(1.347 \mathrm{e}-02)\end{array}$ & $\begin{array}{l}\text { o.j10e-02 } \\
(5.58)\end{array}$ & $\begin{array}{l}8.065-0 e^{a} \\
(1.274 \mathrm{e}-02)\end{array}$ & $\begin{array}{l}7.806 \mathrm{e}-02^{a} \\
(1.304 \mathrm{e}-02)\end{array}$ & $\begin{array}{l}7.777 \mathrm{e}-02^{a} \\
(1.34 \mathrm{e}-02\end{array}$ & $8.239 \mathrm{e}-02^{a}$ \\
\hline Marketshare & $-1.103 \mathrm{e}+05$ & $-5.736 e+04$ & $-1.129 \mathrm{e}+05$ & $-3.607 \mathrm{e}+05$ & $-1.070 \mathrm{e}+05$ & $-5.579 \mathrm{e}+04$ & $-1.032 \mathrm{e}+05$ & $-3.416 \mathrm{e}+05$ \\
\hline & $(1.817 \mathrm{e}+05)$ & $(1.897 \mathrm{e}+05)$ & $(2.164 \mathrm{e}+05)$ & (1.09) & $(1.813 \mathrm{e}+05)$ & $(1.893 \mathrm{e}+05)$ & $(2.163 \mathrm{e}+05)$ & $(3.319 \mathrm{e}+05)$ \\
\hline $\mathrm{HH}$ & $\begin{array}{l}-4.261 \\
(8.468\end{array}$ & $\begin{array}{l}-1.106 \mathrm{e}+01 \\
-1.345 \mathrm{e}+01\end{array}$ & $\begin{array}{l}-1.026 \mathrm{e}+01 \\
-1\end{array}$ & $-1.937 \mathrm{e}+01$ & $\begin{array}{l}-4.187 \\
(8.375)\end{array}$ & $\begin{array}{l}-1.047 \mathrm{e}+01 \\
-1.06\end{array}$ & $\begin{array}{c}-9.765 \\
(1.707 e+01\end{array}$ & $\begin{array}{l}-1.993 \mathrm{e}+01 \\
-(2593 \mathrm{e}+01\end{array}$ \\
\hline Constant & $2.182 \mathrm{e}+04$ & $5.308 \mathrm{e}+04$ & $4.516 \mathrm{e}+04$ & $1.341 \mathrm{e}+05$ & $2.104 \mathrm{e}+04$ & $4.889 \mathrm{e}+04$ & $4.114 \mathrm{e}+04$ & $\begin{array}{c}(2.593 \mathrm{e}+01) \\
1.465 \mathrm{e}+05\end{array}$ \\
\hline & $(7.369 \mathrm{e}+04)$ & $(1.098 \mathrm{e}+05)$ & $(1.435 \mathrm{e}+05)$ & $(0.57)$ & $(7.305 \mathrm{e}+04)$ & $(1.070 \mathrm{e}+05)$ & $(1.389 \mathrm{e}+05)$ & $(2.275 \mathrm{e}+05)$ \\
\hline $\begin{array}{l}\text { Observations } \\
\text { R-sguared }\end{array}$ & 4026 & $\begin{array}{l}2876 \\
0.78\end{array}$ & 2114 & 1563 & 4026 & $\begin{array}{l}2876 \\
0.8\end{array}$ & 2114 & 1563 \\
\hline $\begin{array}{l}\text { ector and ye } \\
\text { lobust stand }\end{array}$ & $\begin{array}{l}\text { d effects } \\
\text { cors in pa }\end{array}$ & ided & & & & & & \\
\hline
\end{tabular}


Beyond the issue of M\&A regulation, cross-border M\&A raise new questions in term of economic policy. Should governments encourage the formation of national champions or facilitate cross-border operations ? Are their effects on firms and host countries identical or different ? Our results clearly question the discrimination attitude to foreign acquisitions regarding the firms' performance. At worse, domestic and foreign acquisitions do not significantly differ in terms of TFP and profit. Depending on the country origin of the buyer, cross-border operations could in some cases engender higher efficiency gains. Our results also cast some doubt on a negative related impact on the national welfare. First, they is no evidence of any increase in market power of target firms. As shown, profits do not vary following a domestic or foreign acquisition. In addition, target firms do not seem to keep their efficiency gains. Two scenarios are possible. First, efficiency gains are only redistributed to the upstream (suppliers/labor force) and/or downstream production stage (consumers). In that case, cross-border M\&A are likely to generate more important (or equal) positive pecuniary spill-overs to the host country's economy. Second, a part of efficiency gains from the acquired affiliate goes to the parent company through transfer pricing mechanisms. Then, drawing a conclusion is less simple, since gains could evade from the host country. If internal prices absorb all efficiency gains, the host country does not profit from gains in efficiency. Only the home country of the parent company wins from foreign acquisitions. A government maximizing the social welfare should then foster domestic operations. However, as discussed previously, this second scenario sounds less plausible in our situation. To definitely validate this assumption, data on buyer firms would be needed. Unfortunately, data constraints do not usually allow researchers to have such an exhaustive and harmonized data on both buyer and target firms' characteristics. This problem is amplified with a large number of home countries.

Finally, as concerns the controlling variables (see also tables in appendix C), the variable Size 
is usually positive and significant in profit regressions, but more ambiguous in TFP regressions. Its sign and significance depend on the set of the independent variables and dummies included. The variable Marketshare does not seem to exert any significant role in the profit level. It often has a negative impact on productivity. The concentration rate are negatively (significantly or not) associated to the TFP and profit.

\section{Conclusion}

This paper explores the repercussions of horizontal acquisitions on the performance of French target firms in the 90's. Using French manufacturing firm-level data (EAE enquiry), we investigate how their profit and their productive efficiency vary. We wonder whether domestic and cross-border M\&A have similar consequences. We implement appropriate difference-in-difference estimation techniques associated to a matching propensity score procedure. We find that M\&A do not raise the profit of French companies, even on the long run. On the contrary, they increase their productivity. It suggests that firms probably redistribute efficiency gains at the upstream and/or downstream production stage. In addition, the implications of domestic M\&A significantly differ from those of cross-border M\&A. Efficiency gains are stronger for cross-border M\&A. This conclusion is however true only for extra-EU operations. The achievement in the European economic integration certainly partly explains the absence of significant difference between European and domestic acquisitions. Our results question the discrimination attitude to cross-border acquisitions regarding their impact on firms' performance as well as the host country's welfare. All these findings clearly deserve further investigations in our future research agenda. 


\section{References}

Andrade, G., Mitchell, M. and Stafford, E. (2001), "New Evidence and Perspectives on Mergers", Journal of Economic Perspectives, vol. 15 n 2: pp. 103-120.

Arnold, J. and Smarzynska, B. (2005), "Gifted Kids or Pushy Parents? Foreign Acquisitions and Plant Performance in Indonesia", CEPR Discussion Paper 5065.

Baldwin, J. (1995), The Dynamics of the Competitive Process, Cambridge University Press, Cambridge.

BALDWin, J. and GoRECKI, P. (1990), Mergers placed in the context of firm turnover, In Bureau of the Census, Annual Research Conference, Proceedings, Washington DC : US Department of Commerce, pp. 53-73.

Bernheim, B. D. and Whinston, M. D. (1990), "Multimarket contact and collusive behaviour", RAND Journal of Economics, vol. 21 n 1: pp. 1-26.

Bertrand, O. and Zitouna, H. (2006), "Trade liberalization and industrial restructuring : the role of cross-border mergers and acquisitions", Journal of Economics and Management Strategy, forthcoming.

Bertrand, O. and ZunigA, P. (2006), "R\&D and M\&A : Are cross-border M\&A different? An Investigation on OECD countries", International Journal of Industrial Organization, vol. 24 $\mathrm{n}^{\mathrm{o}} 2:$ pp. $401-423$.

Blundell, R. and Costa Dias, M. (2000), "Evaluation methods for non-experimental data", Fiscal Studies, vol. 21: pp. 427-468.

Cable, J., Palfrey, J. and Runge, J. (1980), Federal Republic of Germany, 1964-1974, In 
Mueller, D.C. (Ed.), The Determinants and Effects of Mergers : An International Comparison. Oelgeschlager, Gunn \& Hain, Cambridge, MA.

Capron, L. and Mitchell, W. (1998), "Bilateral Resource Redeployment and Capabilities Improvement Following Horizontal Acquisitions", Industrial and Corporate Change, vol. 7 $\mathrm{n}^{\mathrm{O}} 3$ : pp. $453-484$.

Caves, D. W., Christensen, L. R. and Diewert, W. E. (1982), "Multilateral Comparisons of Output, Input, and Productivity Using Superlative Index Numbers", The Economic Journal, vol. $92 \mathrm{n}^{\circ}$ 365: pp. 73-86.

Caves, R. E. (1989), "Mergers, Takeovers, and Economic Efficiency", International Journal of Industrial Organization, vol. 7: pp. 151-174.

Caves, R. E. (1996), Multinational Enterprise and Economic Analysis, Cambridge University Press, Cambridge.

Conyon, M. J., Girma, S., Thompson, S. and Wright, P. (2002), "The productivity and wage effects of foreign acquisition in the United Kingdom", Journal of Industrial Economics, vol. 50: pp. $85-102$.

Cosh, A., Hughes, A. and Singh, A. (1980), The causes and effects of takeovers in the United Kingdom: An empirical investigation for the late 1960s at the microeconomic level, In Mueller, D.C. (Ed.), The Determinants and Effects of Mergers : An International Comparison. Oelgeschlager, Gunn \& Hain, Cambridge, MA, pp. 227-270.

Coutinet, N. and Sagot-Duvauroux, D. (2003), Économie des fusions et acquisitions, Éditions La Découverte.

Davies, S. W. and Lyons, B. R. (1991), "Characterising relative performance: The produc- 
tivity advantage of foreign-owned firms in the UK", Oxford Economic Papers, vol. 43: pp. $584-595$.

Dehejia, R. and Wahba, S. (2002), "Propensity Score-Matching Methods for Nonexperimental Causal Studies", Review of Economics and Statistics, vol. 84 n ${ }^{\circ}$ 1: pp. 151-161.

Derhy, A. (1999), "F\&A : à quelles logiques obéissent-elles ?", Revue Française de Gestion, vol. 122 .

Driffield, N. (1977), Global competition and the labour market, Amsterdam : Harwood Academic Publishers.

Dunning, J. (1981), International Production and the Multinational Enterprise, London, George Allen and Unwin.

Giora, C. and Thomsen, S. (2004), "International acquisitions in the Danish Business : Selection and performance", mimeo.

Girma, S. and Görg, H. (2002), "Foreign Ownership, Returns to scale and Productivity : Evidence from UK Manufacturing Establishments", GEP Discussion Paper No. 3503.

Girma, S. and Görg, H. (2003), "Blessing or Curse? Domestic Plants' Survival and Employment Prospects after Foreign Acquisitions", mimeo.

Girma, S., Greenaway, D., Wakelin, K. and Sousa, N. (2000), Host country effects of FDI in the UK : Recent evidence from firm level data, In Pain N. (ed.), Inward investment, technological change and growth : the impact of multinational corporations on the UK economy. Palgrave Press.

Girma, S., Kneller, R. and Pisu, M. (2003), "Do exporters have anything to learn from foreign multinationals?", University of Nottingham, mimeo. 
GoldBerg, L. (1973), "The effect of conglomerate mergers on competition", Journal of Law and Economics, vol. 16: p. 137-158.

Good, D. H., Nadiri, M. and Sickles, R. C. (1997), Index Number and Factor Demand Approaches to the Estimation of Productivity, In M. Hashem Pesaran \& M. R. Wickens (Eds.), Handbook of Applied Econometrics, Vol. 2, Blackwell Publishers.

Griffith, R. and Simpson, H. (2001), "Characteristics of foreign owned firms in British manufacturing", Institute for Fiscal Studies, Working paper No. 10.

Gugler, K., Mueller, D., Yurtoglu, B. B. and Zulehner, C. (2003), "The Effects of Mergers : An International Comparison", International Journal of Industrial Organization, vol. $21 \mathrm{n}^{0}$ 5: pp. $625-653$.

Harris, R. and Ravenscraft, D. (1991), "The Role of Acquisitions in Foreign Direct Investment : Evidence from the U.S. Stock Market", The Journal of Finance, vol. 46: pp. $825-844$.

Healy, P., Palepu, K. and Ruback, R. (1992), "Does corporate performance improve after mergers?", Journal of Financial Economics, vol. 31: pp. 135-175.

Heckman, J., Ichimura, H., Smith, J. and Todd, P. (1997), "Matching as an Econometric Evaluation Estimator : Evidence from Evaluating a Job Training Programme", Review of Economic Studies, vol. 64: pp. 605-654.

Houdebine, M. and Topiol-BensaïD, A. (1999), "L'investissement direct et les entreprises françaises", Economie Et Statistique, n 326-327.

Hymer, S. (1976), The International Operations of National Firms : A study of direct foreign investment, MIT Press, Cambridge. 
IKEDA, K. and DoI, N. (1983), “The performance of merging firms in Japanese manufacturing industry : 1964-75", Journal of Industrial Economics, vol. 31: p. 257-266.

Jenny, F. and Weber, A. (1980), France, 1962-72, In Mueller, D.C. (Ed.), The Determinants and Effects of Mergers : An International Comparison. Oelgeschlager, Gunn \& Hain, Cambridge, MA.

Jensen (1986), "Agency costs of free cash flow, Corporate Finance and Takeovers", American Economic Review, vol. 76: pp. 323-329.

Kang, N. and Johansson, S. (2000), "Cross-border Mergers and Acquisitions : Their Role in Industrial Globalisation", OECD Working Papers, STI Working Papers 2000/1, vol. 8 n 30 .

Levy, D. and J.Reitzes (1995), "Price Discrimination and Mergers", Canadian Journal of Economics, vol. 28 n $^{\circ} 2$ : pp. $427-36$.

Levy, D. and Reitzes, J. (1992), "Anticompetitive Effects of Mergers in Markets with Localized Competition", The Journal of Law, Economics and Organization, vol. $8 \mathrm{n}^{\mathrm{o}}$ 2: pp. $427-440$.

Lichtenberg, F. and Siegel, D. (1987), "Productivity and changes in ownership of manufacturing Plants", Brookings Papers on Economic Activity, n ${ }^{\circ}$ : pp. 643-673.

Lommerud, K. E., Straume, O. R. and Sørgard, L. (2004), " National versus international mergers in unionised oligopoly", Mimeo.

Markides, C. and ItTner, C. (1994), "Shareholder benefits from corporate international diversification : Evidence from US international acquisitions", Journal of International Business Studies, vol. 25: p. 343-366. 
McDougall, F. and Round, D. (1986), "The Determinants and Effects of Corporate Takeovers in Australia, 1970-1981", Australian Institute of Management, Victoria.

McGuckin, R., Nguyen, S. and Reznek, A. (1995), "The impact of ownership change on employment, wages and labour productivity in US manufacturing 1977-87", Center for Economic Studies, US Bureau of Census, 95-8.

Meeks, G. (1977), Disappointing Marriage : A Study of the Gains From Merger, Cambridge University Press, Cambridge.

Meschi, M. (1997), "Analytical Perspectives on Mergers and Acquisitions : A Survey", South Bank University Centre For International Business Studies, Research Papers in International Business, 5-9\%.

Meyer, B. D. (1994), "Natural and Quasi-Experiments in Economics", NBER Technical Working Paper 170.

Mueller, D. (1985), "Mergers and market share", Review of Economics and Statistics, vol. 67: p. $259-267$.

Pautler, P. A. (2003), "Evidence on Mergers and Acquisitions", Antitrust Bulletin, vol. 48 $\mathrm{n}^{\mathrm{o}}$ 1: pp. 119-221.

PeEr, H. (1980), The Netherlands, 1962-1973, In Mueller, D.C. (Ed.), The Determinants and Effects of Mergers : An International Comparison. Oelgeschlager, Gunn \& Hain, Cambridge, MA, pp. 163-191.

Piscitello, L. and RabBiosi, L. (2003), “Medium Term Effects of Foreign Acquisitions Upon The Target Companies' Performance", mimeo. 
Ravenscraft, D. J. and Scherer, F. M. (1987), "Mergers Sell-offs and Economic Efficiency", The Brookings Institution, Washington DC.

RAVEnscraft, D. J. and Scherer, F. M. (1989), "The profitability of mergers", International Journal of Industrial Organisation, vol. 7: pp. 101-116.

Rosenbaum, P. and Rubin, D. B. (1983), "The central role of the propensity score in observational studies for causal effects", Biometrika, vol. 70: p. 41-55.

Ryden, B. and Edberg, J. (1980), Large mergers in Sweden, 1962-1976, In Mueller, D.C. (Ed.), The Determinants and Effects of Mergers : An International Comparison. Oelgeschlager, Gunn \& Hain, Cambridge, MA, pp. 193-226.

Salant, S. W., Switzer, S. and Reynolds, R. J. (1983), "Losses from Horizontal Merger : The Effects of An Exogenous Change in Industry Structure on Cournot-Nash Equilibrium", Quarterly Journal of Economics, vol. 98 nº 2: pp. 185-199.

Shleifer, A. and Summers, L. (1988), Breach of trust in hostile takeovers, in Auerbach A.J. (Ed.), Corporate Takeovers : Causes and Consequences. University of Chicago Press : Chicago and London.

SiAnESI, B. (2001), "Implementing propensity score matching estimators with STATA", http: //fmwww.bc.edu/RePEc/usug2001/psmatch.pdf.

Swenson, D. (1993), Foreign mergers and acquisitions in the United States, in K.A. Froot, ed., Foreign Direct Investment, University of Chicago Press, Chicago, IL.

UNCTAD (2000), World Investment Report : Cross-Border Mergers and Acquisitions and Development, United Nations. New York \& Geneva. 
VAn Biesebroeck, J. (2003), "Revisiting Some Productivity Debates", NBER Working Paper 10065. 


\section{A Measuring productivity}

The multilateral TFP index is constructed as the log of the firm's output minus a revenue-share weighted sum of the log of firm's inputs. In order to guarantee that comparisons between any two firm-year observations are transitive, firm's inputs and outputs are expressed as deviations from a single reference point. As the reference point, the multilateral index elaborated by Caves, Christensen and Diewert keeps a hypothetical plant whose input revenue shares equal to the arithmetic mean revenue shares over all observations, and output and input levels correspond to the geometric mean of outputs and inputs over all observations. The output, input and consequently productivity of a firm for each year are measured relative to this hypothetical plant. The extension of this method uses a separate hypothetical firm reference point for each cross-section of observations and then chain-links the reference points together over time. This productivity index is useful in our framework since it provides a consistent way of summarizing not only the cross-sectional distribution of firms' TFP, but also how the distribution moves over time. Moreover, it allows flexible specifications of technology.

Formally, we suppose that a plant $f$ produces a single output $y_{f t}$ using the set of inputs $x_{i f t}$ where $i=1,2, \ldots, n$. The total factor productivity index for this plant $f$ in year $t$ is defined as:

$$
\begin{aligned}
\ln T F P_{f t} & =\left(\ln y_{f t}-\overline{\ln y_{t}}\right)+\sum_{s=2}^{t}\left(\overline{\ln y_{s}}-\overline{\ln y_{s-1}}\right) \\
& -\sum_{i=1}^{n} \frac{1}{2}\left(S_{i f t}+\bar{S}_{i t}\right)\left(\ln x_{i f t}-\overline{\ln x_{i t}}\right) \\
& -\sum_{s=2}^{t} \sum_{i=1}^{n} \frac{1}{2}\left(\bar{S}_{i s}+\bar{S}_{i s-1}\right)\left(\overline{\ln x_{i s}}-\overline{\ln x_{i s-1}}\right)
\end{aligned}
$$

where $\overline{\ln y}=\frac{1}{m} \sum_{f=1}^{m} \ln y_{f}, \overline{\ln x_{i}}=\frac{1}{m} \sum_{f=1}^{m} \ln x_{i f}$ and $\bar{S}_{i}=\frac{1}{m} \sum_{f=1}^{m} S_{i f t}$. 
The first term expresses the firm's output in year $t$ as a deviation from the reference point, that says the geometric mean output over all plants in year $t$. It captures information on the cross-sectional distribution in outputs. The second term adds changes in the output reference point across all years. It provides information on the shift of the output distribution over time by chain-linking the movement in the reference point. The remaining two terms perform the same operation for each input $x_{i}$. Inputs are then added using a combination of firm factor shares $S_{i t}$ and average factor shares $\overline{S_{i t}}$ for each year as weights.

In our study, the production is approximated by the turnover, from which we withdraw the variation in stocks (goods and raw materials stocks; see Girma et al. (2003)). In addition, we deflate it using the sectoral production price index. ${ }^{43}$ Besides, we include four kinds of inputs in our computation: labor, intermediate goods, subcontracting and capital. Labor, intermediate goods and subcontracting are measured respectively by the number of employees, the purchases of intermediate goods (deflated by the intermediate goods price index) and subcontracting (deflated by the production price index). The capital is evaluated by the sum of companies' tangible and intangible fixed assets (deflated by the GFCF price index).

\footnotetext{
${ }^{43}$ All indexes (source: INSEE) are calculated at a sector-level (base 100 in 1995).
} 


\section{B Summary Statistics}

Table 8: Statistics on French firms (EAE enquiry)

\begin{tabular}{|l|c|c|c|c|c|c|c|}
\hline & Size & Profit & TFP & Wage & Export & Marketshare & HH \\
\hline mean & 172074 & 15531.62 & -1.716 & 210.066 & .147 & .013 & 583.368 \\
sd & 172074 & 437498.4 & 1.803 & 78.836 & .219 & .051 & 946.363 \\
\hline
\end{tabular}

\section{Matching procedure}

Table 9: Comparison between target firms and the control group (domestic M\&A)

\begin{tabular}{|c|c|c|c|c|c|}
\hline \multirow[t]{2}{*}{ Variable } & \multirow{2}{*}{ Sample } & \multicolumn{2}{|c|}{ Mean } & \multirow[t]{2}{*}{ Bias } & \multirow[t]{2}{*}{ Reduction in bias } \\
\hline & & Treated & Controls & & \\
\hline \multirow[t]{2}{*}{ Profit } & Unmatched & 19183.73 & 16754.44 & 0.7 & \multirow[b]{2}{*}{31.1} \\
\hline & Matched & 19183.73 & 20856.34 & -0.5 & \\
\hline \multirow[t]{2}{*}{ TFP } & Unmatched & -2.326 & -1.616 & -41.9 & \multirow[b]{2}{*}{89.7} \\
\hline & Matched & -2.325 & -2.2520 & -4.3 & \\
\hline \multirow[t]{2}{*}{ Marketshare } & Unmatched & .031 & .0127 & 21.4 & \multirow[b]{2}{*}{76.8} \\
\hline & Matched & .031 & .035 & -5.0 & \\
\hline \multirow[t]{2}{*}{ Export } & Unmatched & .250 & .149 & 42.5 & \multirow[b]{2}{*}{88.4} \\
\hline & Matched & .250 & .262 & -4.9 & \\
\hline \multirow[t]{2}{*}{ Export $^{2}$} & Unmatched & .13 & .070 & 32.5 & \multirow[b]{2}{*}{78.2} \\
\hline & Matched & .13 & .146 & -7.1 & \\
\hline \multirow[t]{2}{*}{ Wage } & Unmatched & 231.457 & 210.519 & 24.7 & \multirow[b]{2}{*}{96.8} \\
\hline & Matched & 231.457 & 232.13 & -0.8 & \\
\hline \multirow[t]{2}{*}{ Wage $^{2}$} & Unmatched & 62014.27 & 50156.43 & 10.2 & \multirow[b]{2}{*}{79.8} \\
\hline & Matched & 62014.27 & 59619.66 & 2.1 & \\
\hline
\end{tabular}


Table 10: Comparison between target firms and the control group (cross-border M\&A)

\begin{tabular}{|c|c|c|c|c|c|}
\hline \multirow[t]{2}{*}{ Variable } & \multirow[t]{2}{*}{ Sample } & \multicolumn{2}{|c|}{ Mean } & \multirow[t]{2}{*}{ Bias } & \multirow[t]{2}{*}{ Reduction in bias } \\
\hline & & Treated & Controls & & \\
\hline \multirow[t]{2}{*}{ Profit } & Unmatched & 29984.36 & 16949.64 & 3.8 & \multirow[b]{2}{*}{31.0} \\
\hline & Matched & 29984.36 & 20992.08 & 2.6 & \\
\hline \multirow[t]{2}{*}{ TFP } & Unmatched & -2.446 & -1.615 & -48.7 & \multirow[b]{2}{*}{97.9} \\
\hline & Matched & -2.446 & -2.463 & 1.0 & \\
\hline \multirow[t]{2}{*}{ Marketshare } & Unmatched & .036 & .012 & 31.6 & \multirow[b]{2}{*}{50.5} \\
\hline & Matched & .036 & .021 & 15.6 & \\
\hline \multirow[t]{2}{*}{ Export } & Unmatched & .272 & .148 & 54.1 & \multirow[b]{2}{*}{86.9} \\
\hline & Matched & .272 & .288 & -7.1 & \\
\hline \multirow[t]{2}{*}{ Export $^{2}$} & Unmatched & .131 & .069 & 35.3 & \multirow[b]{2}{*}{75.7} \\
\hline & Matched & .131 & .145 & -8.6 & \\
\hline \multirow[t]{2}{*}{ Wage } & Unmatched & 249.688 & 210.608 & 52.8 & \multirow[b]{2}{*}{89.1} \\
\hline & Matched & 249.688 & 253.947 & -5.8 & \\
\hline \multirow[t]{2}{*}{ Wage $^{2}$} & Unmatched & 67439.6 & 50168 & 17.0 & \multirow[b]{2}{*}{80.5} \\
\hline & Matched & 67439.6 & 70803.75 & -3.3 & \\
\hline
\end{tabular}

Table 11: Propensity score step

\begin{tabular}{|l|c|c|}
\hline determinants & domestic M\&A & cross-border M\&A \\
\hline Profit & $-1.75 \mathrm{e}-07$ & $-4.11 \mathrm{e}-08$ \\
TFP & $(2.35 \mathrm{e}-07)$ & $(1.38 \mathrm{e}-07)$ \\
& $-0.059^{a}$ & $-0.063^{a}$ \\
Marketshare & $(0.014)$ & $(0.016)$ \\
& $0.569^{b}$ & 0.325 \\
Export & $(0.253)$ & $(0.301)$ \\
& $1.004^{a}$ & $1.799^{a}$ \\
Export & $(0.258)$ & $(0.297)$ \\
& $-0.837^{b}$ & $-1.899^{a}$ \\
Wage & $(0.332)$ & $(0.397)$ \\
& $0.001^{b}$ & $0.006^{a}$ \\
Wage & $(0.0004)$ & $(0.002)$ \\
& $-2.95 \mathrm{e}-07$ & $-7.63 \mathrm{e}-06^{a}$ \\
Constant & $(3.90 \mathrm{e}-07)$ & $(2.68 \mathrm{e}-06)$ \\
\multicolumn{2}{|c|}{$-3.467^{a}$} & $-4.385^{a}$ \\
Observations & $(0.086)$ & $(0.211)$ \\
Log likelihood & 182148 & 181902 \\
Pseudo R2 & -1562.913 & -1302.152 \\
\hline Standard errors in parentheses & 0.054 \\
${ }^{c}$ significant at $10 \%{ }^{b}$ significant at $5 \%$ \\
${ }^{a}$ significant at $1 \%$ \\
\hline \multicolumn{2}{|c}{} \\
\hline \multicolumn{2}{|c}{} \\
\hline
\end{tabular}




\title{
Domestic versus cross-border acquisitions: which impact on the
}

\author{
target firms' performance?
}

Additional results: firms fixed effects and no fixed effects

Table 1: Effects of M\&A on TFP (firm fixed effects)

\begin{tabular}{|c|c|c|c|c|c|c|c|c|c|c|}
\hline & (1) & (2) & (3) & (4) & $(5)$ & (6) & (7) & $(8)$ & (9) & (10) \\
\hline After & $-1.251^{a}$ & $-1.259^{a}$ & $-1.260^{a}$ & $-1.257^{a}$ & $-1.258^{a}$ & $-1.251^{a}$ & $-1.258^{a}$ & $-1.260^{a}$ & $-1.257^{a}$ & $-1.259^{a}$ \\
\hline & .049 & .049 & .049 & .049 & .049 & .049 & .049 & .049 & .049 & .049 \\
\hline $\mathrm{AF}$ & $-.966^{a}$ & $3.077^{a}$ & $1.981^{a}$ & $3.680^{a}$ & $2.222^{a}$ & & & & & \\
\hline AF Dom & .280 & .185 & .726 & .374 & .773 & $\begin{array}{c}3.078^{a} \\
.184\end{array}$ & $\begin{array}{l}2.781^{a} \\
.180\end{array}$ & $\begin{array}{l}1.220^{c} \\
.645\end{array}$ & $\begin{array}{l}2.994^{a} \\
.224\end{array}$ & $\begin{array}{c}1.552^{b} \\
.748\end{array}$ \\
\hline AF $\operatorname{Trs}$ & & & & & & .354 & $-.676^{b}$ & $-.677^{c}$ & $1.683^{b}$ & $1.457^{c}$ \\
\hline AF*After & $.191^{a}$ & $.192^{a}$ & $.190^{a}$ & $.191^{a}$ & $.190^{a}$ & .797 & .386 & .386 & .837 & .848 \\
\hline AF Dom*After & & .008 & .068 & & .068 & .049 & .051 & .046 & .052 & .047 \\
\hline & & & & & & $\begin{array}{l}.083 \\
356^{a}\end{array}$ & .083 & $\begin{array}{l}.083 \\
357^{a}\end{array}$ & .083 & $\begin{array}{l}.083 \\
355^{a}\end{array}$ \\
\hline AF Trs*After & & & & & & $\begin{array}{l}.356^{a} \\
.083\end{array}$ & $\begin{array}{l}.356^{a} \\
.083\end{array}$ & $\begin{array}{l}.357^{a} \\
.083\end{array}$ & $\begin{array}{l}.353^{a} \\
.083\end{array}$ & $\begin{array}{l}.355^{a} \\
.083\end{array}$ \\
\hline Size & & $\begin{array}{c}7.87 \mathrm{e}-08^{a} \\
2.10 \mathrm{e}-08\end{array}$ & $\begin{array}{c}1.05 \mathrm{e}-07^{b} \\
2.33 \mathrm{e}-08\end{array}$ & $\begin{array}{c}8.26 \mathrm{e}-08^{a} \\
2.14 \mathrm{e}-08\end{array}$ & $\begin{array}{c}1.03 \mathrm{e}-07^{a} \\
2.31 \mathrm{e}-08\end{array}$ & & $\begin{array}{c}7.73 \mathrm{e}-08^{a} \\
2.05 \mathrm{e}-08\end{array}$ & $\begin{array}{c}1.05 \mathrm{e}-07^{a} \\
2.33 \mathrm{e}-08\end{array}$ & $\begin{array}{c}8.10 \mathrm{e}-08^{a} \\
2.10 \mathrm{e}-08\end{array}$ & $\begin{array}{c}1.03 \mathrm{e}-07^{a} \\
2.31 \mathrm{e}-08\end{array}$ \\
\hline Marketshare & & & $\begin{array}{c}-1.825^{a} \\
.637\end{array}$ & & $\begin{array}{c}-1.479^{b} \\
.704\end{array}$ & & & $\begin{array}{c}-1.893^{a} \\
.632\end{array}$ & & $\begin{array}{c}-1.575^{b} \\
.699\end{array}$ \\
\hline $\mathrm{HH}$ & & & & $\begin{array}{c}-.000^{c} \\
000\end{array}$ & $\begin{array}{c}-.000 \\
000\end{array}$ & & & & $\begin{array}{l}-.000 \\
000\end{array}$ & $\begin{array}{c}-.000 \\
000\end{array}$ \\
\hline Constant & $\begin{array}{c}-2.440^{a} \\
.041\end{array}$ & $\begin{array}{c}-2.737^{a} \\
.058\end{array}$ & $\begin{array}{c}-3.282^{a} \\
.341\end{array}$ & $\begin{array}{c}-3.104^{a} \\
.350\end{array}$ & $\begin{array}{c}-3.150^{a} \\
.356\end{array}$ & $\begin{array}{c}-2.735^{a} \\
.057\end{array}$ & $\begin{array}{c}-2.441^{a} \\
.041\end{array}$ & $\begin{array}{c}-2.438 \\
.041\end{array}$ & $\begin{array}{c}-2.427^{a} \\
.042\end{array}$ & $\begin{array}{c}-2.429^{a} \\
.042\end{array}$ \\
\hline Observations & 6380 & 6380 & 6380 & 6380 & 6380 & 6380 & 6380 & 6380 & 6380 & 6380 \\
\hline R-squared & 0.4042 & 0.4045 & 0.4049 & 0.4047 & 0.4050 & 0.4051 & 0.4053 & 0.4057 & 0.4045 & 0.4058 \\
\hline
\end{tabular}


Table 2: Effects of intra-EU and extra-EU cross-border M\&A on TFP (firm fixed effects)

\begin{tabular}{|l|c|}
\hline & TFP \\
\hline After & $-1.259^{a}$ \\
AF Dom & .049 \\
& $2.279^{a}$ \\
AF Trs E & .769 \\
& .125 \\
AF Trs NE & .541 \\
& $2.172^{b}$ \\
AF Dom*After & .862 \\
& .048 \\
AF Trs E*After & .084 \\
& $.205^{b}$ \\
AF Trs NE*After & .104 \\
& $.572^{a}$ \\
Size & .110 \\
& $9.98 \mathrm{e}-08^{a}$ \\
Marketshare & $2.29 \mathrm{e}-08$ \\
& $-1.512^{b}$ \\
HH & .697 \\
& -.000 \\
Constant & .000 \\
\multicolumn{2}{|c|}{ Observations } \\
R-squared & $.3 .148^{a}$ \\
\hline firm fixed effects are included. \\
Robust standard errors in parentheses \\
$b$ significant at $5 \%{ }^{a}$ significant at $1 \%$ \\
\hline \multicolumn{2}{|c|}{} \\
\hline
\end{tabular}

Table 3: Effects of M\&A on TFP (no fixed effects)

\begin{tabular}{|c|c|c|c|c|c|c|c|c|c|c|}
\hline & $(1)$ & $(2)$ & $(3)$ & $(4)$ & $(5)$ & $(6)$ & $(7)$ & $(8)$ & $(9)$ & $(10)$ \\
\hline After & $-1.131^{a}$ & $-1.119^{a}$ & $-1.122^{a}$ & $-1.123^{a}$ & $-1.121^{a}$ & $-1.131^{a}$ & $-1.119^{a}$ & $-1.122^{a}$ & $-1.124^{a}$ & $-1.122^{a}$ \\
\hline & $(.049)$ & $(.049)$ & $(.049)$ & $(.049)$ & $(.049)$ & $(.049)$ & $(.049)$ & $(.049)$ & $(.049)$ & $(.049)$ \\
\hline $\mathrm{AF}$ & $-.283^{a}$ & $-.270^{a}$ & $-.277^{a}$ & $-.264^{a}$ & $-.277^{a}$ & & & & & \\
\hline AF Dom & $(.058)$ & $(.058)$ & $(.058)$ & $(.058)$ & $(.058)$ & $-.194^{a}$ & $-.194^{a}$ & $-189^{a}$ & $-181^{a}$ & $-189^{a}$ \\
\hline (2) & & & & & & $(.07)$ & $(.069)$ & $(.069)$ & $(.069)$ & $(.069)$ \\
\hline AF $\operatorname{Trs}$ & & & & & & $-.390^{a}$ & $-.361^{a}$ & $-.383^{a}$ & $-.363^{a}$ & $-.383^{a}$ \\
\hline $\mathrm{AF}^{*} \mathrm{After}$ & $239^{a}$ & $249^{a}$ & $248^{a}$ & $248^{a}$ & $249^{a}$ & $(.072)$ & $(.072)$ & $(.072)$ & $(.072)$ & $(.072)$ \\
\hline AT Fiver & $(.068)$ & $(.068)$ & $(.067)$ & $(.068)$ & $(.068)$ & & & & & \\
\hline AF Dom*After & & & & & & $.152^{c}$ & $.146^{c}$ & $.142^{c}$ & $.141^{c}$ & $.142^{c}$ \\
\hline AF Trs*After & & & & & & $\begin{array}{l}(0.08) \\
.343^{a}\end{array}$ & $\begin{array}{l}(0.08) \\
.371^{a}\end{array}$ & $\begin{array}{l}(0.08) \\
.374^{a}\end{array}$ & $\begin{array}{l}(0.08) \\
.375^{a}\end{array}$ & $\begin{array}{l}(0.08) \\
374^{a}\end{array}$ \\
\hline AF ITS AILET & & & & & & $(0.085)$ & $(0.085)$ & $(0.085)$ & $(0.085)$ & $(0.085)$ \\
\hline Size & & $\begin{array}{r}-1.01 \mathrm{e}-07^{a} \\
(1.94 \mathrm{e}-08)\end{array}$ & $\begin{array}{r}-5.38 \mathrm{e}-08^{a} \\
(1.46 \mathrm{e}-08)\end{array}$ & $\begin{array}{r}-9.08 \mathrm{e}-08^{a} \\
(1.79 \mathrm{e}-08)\end{array}$ & $\begin{array}{r}-5.33 \mathrm{e}-08^{a} \\
(1.46 \mathrm{e}-08\end{array}$ & & $\begin{array}{r}-9.96 \mathrm{e}-08^{a} \\
(1.91 \mathrm{e}-08\end{array}$ & $\begin{array}{r}-5.19 \mathrm{e}-08^{a} \\
(1.42 \mathrm{e}-08\end{array}$ & $-8.94 \mathrm{e}-08^{a}$ & $-5.15 \mathrm{e}-08^{a}$ \\
\hline Marketshare & & & $\begin{array}{c}-2.259^{a} \\
(.162)\end{array}$ & $(1.1 .50-00)$ & $\begin{array}{c}-2.318^{a} \\
(.217)\end{array}$ & & & $\begin{array}{c}-2.279^{a} \\
(.160)\end{array}$ & $(1.10 \mathrm{e}-08)$ & $\begin{array}{c}-2.331^{a} \\
(.216)\end{array}$ \\
\hline $\mathrm{HH}$ & & & & $\begin{array}{l}-9.17 \mathrm{e}-05^{a} \\
(1.52 \mathrm{e}-05)\end{array}$ & $\begin{array}{c}7.63 \mathrm{e}-06 \\
(2.01 \mathrm{e}-05)\end{array}$ & & & & $\begin{array}{r}-9.31 \mathrm{e}-05^{a} \\
(1.53 \mathrm{e}-05)\end{array}$ & $\begin{array}{c}6.66 \mathrm{e}-06 \\
(2.01 \mathrm{e}-05)\end{array}$ \\
\hline Constant & $\begin{array}{c}-1.697^{a} \\
(.429) \\
\end{array}$ & $\begin{array}{c}-1.675^{a} \\
(.042) \\
\end{array}$ & $\begin{array}{c}-1.617^{a} \\
(.043) \\
\end{array}$ & $\begin{array}{c}-1.606^{a} \\
(.044) \\
\end{array}$ & $\begin{array}{c}-1.621^{a} \\
(.044)\end{array}$ & $\begin{array}{c}-1.697^{a} \\
(.042)\end{array}$ & $\begin{array}{c}-1.675^{a} \\
(.042)\end{array}$ & $\begin{array}{c}-1.617^{a} \\
(.043)\end{array}$ & $\begin{array}{c}-1.605^{a} \\
(.043)\end{array}$ & $\begin{array}{c}-1.621^{a} \\
(.042)\end{array}$ \\
\hline Observations & 6380 & 6380 & 6380 & 6380 & 6380 & 6380 & 6380 & 6380 & 6380 & 6380 \\
\hline R-squared & 0.09 & 0.10 & 0.11 & 0.10 & 0.11 & 0.09 & 0.10 & 0.12 & 0.10 & 0.12 \\
\hline
\end{tabular}


Table 4: Effects of M\&A on profits (no fixed effects)

\begin{tabular}{|c|c|c|c|c|c|c|c|c|c|c|}
\hline & (1) & (2) & (3) & (4) & (5) & (6) & (7) & (8) & (9) & (10) \\
\hline After & $\begin{array}{l}9607^{b} \\
(4045)\end{array}$ & $\begin{array}{c}221 \\
(3299)\end{array}$ & $\begin{array}{c}272 \\
(3311)\end{array}$ & $\begin{array}{c}214 \\
(3306)\end{array}$ & $\begin{array}{c}177 \\
(3306)\end{array}$ & $\begin{array}{l}9607^{b} \\
(4045)\end{array}$ & $\begin{array}{c}202 \\
(3298)\end{array}$ & $\begin{array}{c}252 \\
(331)\end{array}$ & $\begin{array}{c}190 \\
(3305)\end{array}$ & $\begin{array}{c}155 \\
(3305)\end{array}$ \\
\hline $\mathrm{AF}$ & $\begin{array}{l}5082^{b} \\
(2153)\end{array}$ & $\begin{array}{l}-4429^{b} \\
(1745)\end{array}$ & $\begin{array}{c}-4312^{b} \\
(1789)\end{array}$ & $\begin{array}{r}-4418^{a} \\
(1697)\end{array}$ & $\begin{array}{l}-4077^{b} \\
(1770)\end{array}$ & & & & & \\
\hline AF Dom & & & & & & $\begin{array}{c}392 \\
(2289)\end{array}$ & $\begin{array}{c}671.9 \\
(1.31 \mathrm{e}+03)\end{array}$ & $\begin{array}{c}603.1 \\
(1.28 \mathrm{e}+03)\end{array}$ & $\begin{array}{c}704.4 \\
(1.28 \mathrm{e}+03)\end{array}$ & $\begin{array}{c}909 \\
(1.26 \mathrm{e}+03)\end{array}$ \\
\hline AF $\operatorname{Trs}$ & & & & & & $\begin{array}{r}10670^{a} \\
(3413)\end{array}$ & $\begin{array}{r}-1.05 \mathrm{e}+04^{a} \\
(3.31 \mathrm{e}+03)\end{array}$ & $\begin{array}{r}-1.02 \mathrm{e}+04^{a} \\
(3.45 \mathrm{e}+03)\end{array}$ & $\begin{array}{r}-1.05 \mathrm{e}+04^{a} \\
(3.32 \mathrm{e}+03)\end{array}$ & $\begin{array}{r}-1.00 \mathrm{e}+04^{a} \\
(3.44 \mathrm{e}+03)\end{array}$ \\
\hline $\mathrm{AF}^{*}$ After & $\begin{array}{c}9437 \\
(9389)\end{array}$ & $\begin{array}{c}2259 \\
(5619)\end{array}$ & $\begin{array}{c}2294 \\
(5612)\end{array}$ & $\begin{array}{c}2258 \\
(5618)\end{array}$ & $\begin{array}{c}2303 \\
(5610)\end{array}$ & & & & & \\
\hline AF Dom*After & & & & & & $\begin{array}{l}-6354 \\
(5890)\end{array}$ & $\begin{array}{l}-1540 \\
(4312)\end{array}$ & $\begin{array}{l}-1468 \\
(4284)\end{array}$ & $\begin{array}{l}-1553 \\
(4314)\end{array}$ & $\begin{array}{c}-1570 \\
(4290)\end{array}$ \\
\hline AF Trs*After & & & & & & $\begin{array}{c}27660 \\
(18050)\end{array}$ & $\begin{array}{c}6792 \\
(9666)\end{array}$ & $\begin{array}{c}6776 \\
(9676)\end{array}$ & $\begin{array}{c}6806 \\
(9683)\end{array}$ & $\begin{array}{l}6918 \\
(9669)\end{array}$ \\
\hline Size & & $\begin{array}{l}.074^{a} \\
(.008)\end{array}$ & $\begin{array}{l}.073^{a} \\
(.092)\end{array}$ & $\begin{array}{l}.074^{a} \\
(.087)\end{array}$ & $\begin{array}{l}.073^{a} \\
(.092)\end{array}$ & & $\begin{array}{c}.074^{a} \\
(8.62 \mathrm{e}-03)\end{array}$ & $\begin{array}{c}0.073^{a} \\
(9.23 \mathrm{e}-03)\end{array}$ & $\begin{array}{c}.074^{a} \\
(8.74 \mathrm{e}-03)\end{array}$ & $\begin{array}{c}.073^{a} \\
(9.24 \mathrm{e}-03)\end{array}$ \\
\hline Marketshare & & & $\begin{array}{c}38560 \\
(36000)\end{array}$ & & $\begin{array}{c}59460 \\
(37070)\end{array}$ & & & $\begin{array}{c}37230 \\
(36080)\end{array}$ & & $\begin{array}{c}58470 \\
(37060)\end{array}$ \\
\hline $\mathrm{HH}$ & & & & $\begin{array}{c}-.168 \\
(1.685)\end{array}$ & $\begin{array}{c}-2.701^{a} \\
(.957)\end{array}$ & & & & $\begin{array}{c}-.258 \\
(1.688)\end{array}$ & $\begin{array}{l}-2.74^{a^{\prime}} \\
(.958)\end{array}$ \\
\hline Constant & $\begin{array}{r}19380^{a} \\
(1145)\end{array}$ & $\begin{array}{c}2695 \\
(2056)\end{array}$ & $\begin{array}{c}1708 \\
(1513)\end{array}$ & $\begin{array}{l}2821^{c} \\
(1657)\end{array}$ & $\begin{array}{l}3200^{c} \\
(1716)\end{array}$ & $\begin{array}{r}19380^{a} \\
(1145)\end{array}$ & $\begin{array}{c}2660 \\
(2054)\end{array}$ & $\begin{array}{c}1708 \\
(1508)\end{array}$ & $\begin{array}{l}2854^{c} \\
(1646)\end{array}$ & $\begin{array}{c}3226^{c} \\
(1706)\end{array}$ \\
\hline Observations & 6897 & 6897 & 6897 & 6897 & 6897 & 6897 & 6897 & 6897 & 6897 & 6897 \\
\hline R-squared & 0.00 & 0.59 & 0.59 & 0.59 & 0.59 & 0.01 & 0.59 & 0.59 & 0.59 & 0.59 \\
\hline
\end{tabular}

Table 5: Effects of M\&A on profits (firm fixed effects)

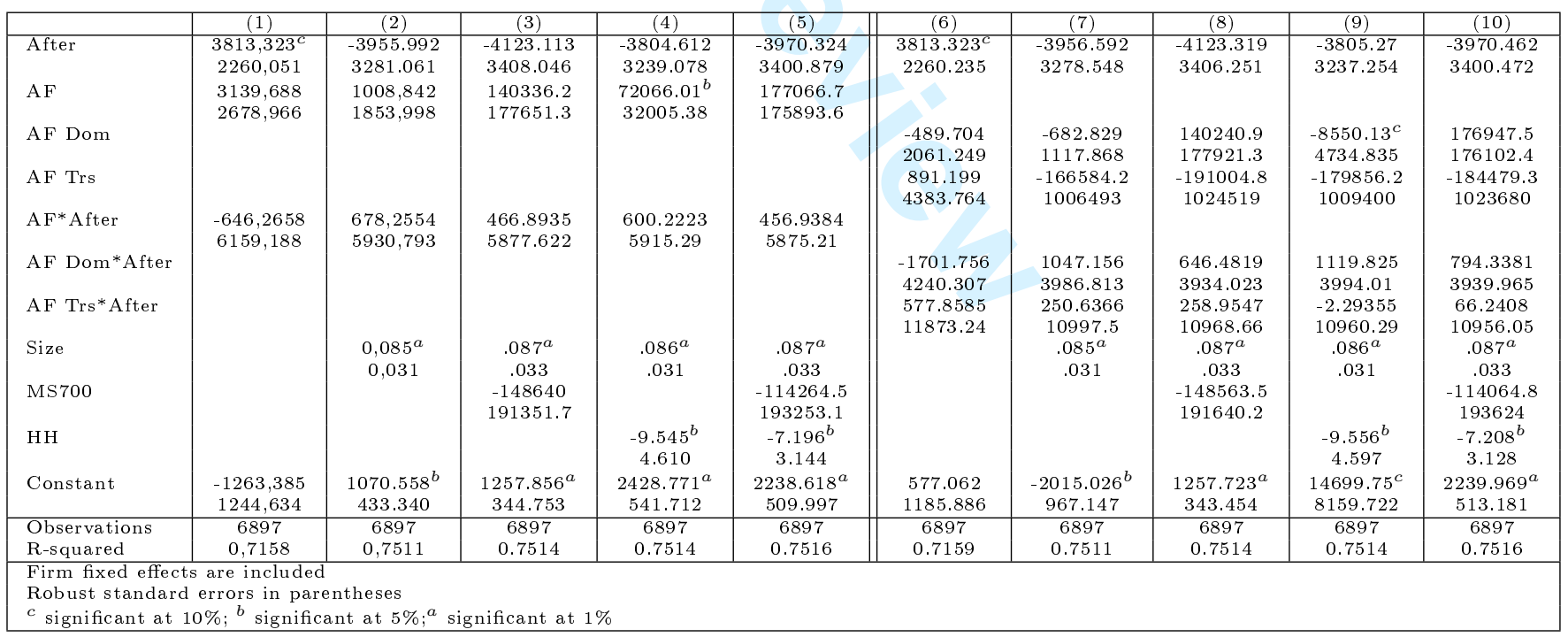

